Utah State University

DigitalCommons@USU

All U.S. Government Documents (Utah Regional U.S. Government Documents (Utah Regional Depository)

Depository)

3-1999

\title{
Classification of Great Basin Plant Communities Occurring on Dugway Proving Ground, Utah
}

Vel Emrick

Alison Hill

Follow this and additional works at: https://digitalcommons.usu.edu/govdocs

Part of the Earth Sciences Commons, and the Environmental Sciences Commons

\section{Recommended Citation}

Emrick, Vel and Hill, Alison, "Classification of Great Basin Plant Communities Occurring on Dugway Proving Ground, Utah" (1999). All U.S. Government Documents (Utah Regional Depository). Paper 67. https://digitalcommons.usu.edu/govdocs/67

This Report is brought to you for free and open access by the U.S. Government Documents (Utah Regional Depository) at DigitalCommons@USU. It has been accepted for inclusion in All U.S. Government Documents (Utah Regional Depository) by an authorized administrator of DigitalCommons@USU. For more information, please contact digitalcommons@usu.edu.

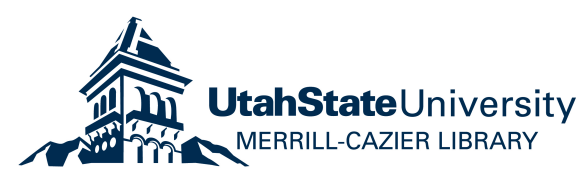


US Army Corps

of Engineers

Construction Engineering

USACERL Technical Report 99/30

Research Laboratory

March 1999

\section{Classification of Great Basin Plant Communities Occurring on Dugway Proving Ground, Utah}

Verl Emrick and Alison Hill
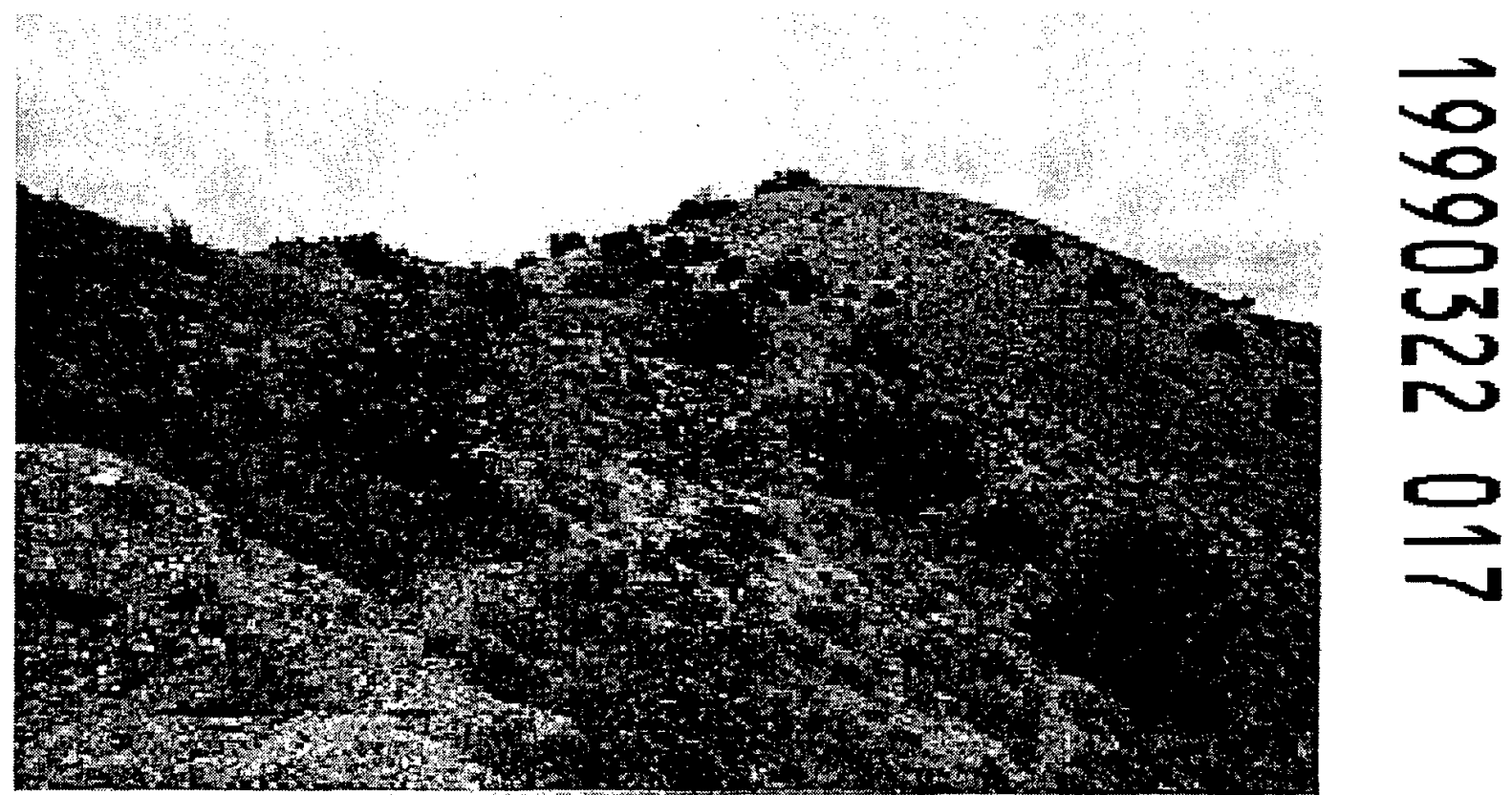

In 1996, staff with Dugway Proving Ground (DPG) and the U.S. Army Construction Engineering Research Laboratory (CERL) launched a project to classify and describe plant communities occurring at DPG. The goal of the project was to use field data to derive a plant community classification system specific to DPG. The classification followed, with certain modifications, the framework of the Nature Conservancy's Standardized National Vegetation Classification System (SNVCS). The SNVCS is a hierarchical system that summarizes plant communities at four physiognomic and two floristic levels. A total of 500 releves were inventoried during the summers of 1996 and 1997. The field data were subjected to several multivariate classification techniques, including hierarchical and nonhierarchical cluster analysis, and multidimensional scaling. Four physiognomic classes, 5 formations, 17 alliances, and 26 associations were identified at DPG. The results of the derived classification will subsequently be used to assist in mapping the vegetative communities at $D P G$.

\section{DTIC QUALFIY DTOPDCIIPD 1}


The contents of this report are not to be used for advertising, publication, or promotional purposes. Citation of trade names does not constitute an official endorsement or approval of the use of such commercial products. The findings of this report are not to be construed as an official Department of the Army position, unless so designated by other authorized documents.

DESTROY THIS REPORT WHEN IT IS NO LONGER NEEDED

DO NOT RETURN IT TO THE ORIGINATOR 


\section{USER EVALUATION OF REPORT}

\section{REFERENCE: USACERL Technical Report 99/30, Classification of Great Basin Plant Communities Occurring on Dugway Proving Ground, Utah}

Please take a few minutes to answer the questions below, tear out this sheet, and return it to USACERL. As user of this report, your customer comments will provide USACERL with information essential for improving future reports.

1. Does this report satisfy a need? (Comment on purpose, related project, or other area of interest for which report will be used.)

2. How, specifically, is the report being used? (Information source, design data or procedure, management procedure, source of ideas, etc.)

3. Has the information in this report led to any quantitative savings as far as manhours/contract dollars saved, operating costs avoided, efficiencies achieved, etc.? If so, please elaborate.

4. What is your evaluation of this report in the following areas?

a. Presentation:

b. Completeness:

c. Easy to Understand:

d. Easy to Implement:

e. Adequate Reference Material:

f. Relates to Area of Interest:

g. Did the report meet your expectations?

h. Does the report raise unanswered questions? 
i. General Comments. (Indicate what you think should be changed to make this report and future reports of this type more responsive to your needs, more usable, improve readability, etc.)

5. If you would like to be contacted by the personnel who prepared this report to raise specific questions or discuss the topic, please fill in the following information.

\section{Name:}

Telephone Number:

Organization Address:

6. Please mail the completed form to:

Department of the Army

CONSTRUCTION ENGINEERING RESEARCH LABORATORIES

ATTN: CECER-TR-I

P.O. Box 9005

Champaign, IL 61826-9005 
Public reporting burden for this collection of information is estimated to average 1 hour per response, including the time for reviewing instructions, searching existing data sources, gathering and maintaining the data needed, and completing and reviewing the collection of information. Send comments regarding this burden estimate or any other aspect of this collection of information, including suggestions for reducing this burden, to Washington Headquarters Services, Directorate for intormation Operations and Reports, 1215 Jeflerson Davis Highway, Suite 1204, Arlington, VA 22202-4302, and to the Office of Management and Budget, Paperwork Reduction Project (0704-0188), Washington, DC 20503.

\begin{tabular}{|l|l|l|}
\hline 1. AGENCY USE ONLY (Leave Blank) & $\begin{array}{l}\text { 2. REPORT DATE } \\
\text { March } 1999\end{array}$ & $\begin{array}{l}\text { 3. REPORT TYPE AND DATES COVERED } \\
\text { Final }\end{array}$ \\
\hline 4. TITLE AND SUBTITLE & \begin{tabular}{l} 
5. FUNDING \\
\hline
\end{tabular}
\end{tabular}

Classification of Great Basin Plant Communities Occurring on Dugway Proving Ground, Utah MIPR

6. AUTHOR(S)

Verl Emrick and Alison Hill

7. PERFORMING ORGANIZATION NAME(S) AND ADDRESS(ES)

U.S. Army Construction Engineering Research Laboratory (USACERL)

P.O. Box 9005

Champaign, IL 61826-9005

B2-6-8C833-B2-MB

9. SPONSORING / MONITORING AGENCY NAME(S) AND ADDRESS(ES)

U.S. Army Garrison

ATTN: STEDP-EP-CP

Dugway Proving Ground, UT 84022

11. SUPPLEMENTARY NOTES

Copies are available from the National Technical Information Service, 5285 Port Royal Road, Springfield, VA 22161.

12a. DISTRIBUTION / AVAILABILITY STATEMENT

12b. DISTRIBUTION CODE

Approved for public release; distribution is unlimited.

13. ABSTRACT (Maximum 200 words)

In 1996, staff with Dugway Proving Ground (DPG) and the U.S. Army Construction Engineering Research Laboratory (CERL) launched a project to classify and describe plant communities occurring at DPG. The goal of the project was to use field data to derive a plant community classification system specific to DPG. The classification followed, with certain modifications, the framework of the Nature Conservancy's Standardized National Vegetation Classification System (SNVCS). The SNVCS is a hierarchical system that summarizes plant communities at four physiognomic and two floristic levels. A total of 500 releves were inventoried during the summers of 1996 and 1997. The field data were subjected to several multivariate classification techniques, including hierarchical and nonhierarchical cluster analysis, and multidimersional scaling. Four physiognomic classes, 5 formations, 17 alliances, and 26 associations were identified at DPG. The results of the derived classification will subsequently be used to assist in mapping the vegetative communities at DPG

14. SUBJECT TERMS

Dugway Proving Ground, UT plant communities natural resource management

17. SECURITY CLASSIFICATION OF REPORT Unclassified
18. SECURITY CLASSIFICATION OF THIS PAGE Unclassified plant classification Great Basin
15. NUMBER OF PAGES 56

16. PRICE CODE

20. LIMITATION OF

ABSTRACT

SAR 


\section{Foreword}

This study was conducted for the Commander, U.S. Army Garrison (USAG), Dugway Proving Ground, under Military Interdepartmental Purchase Request (MIPR) B2-6-8C833-B2-MB, Work Unit "Vegetation Mapping at Dugway Proving Ground." The technical monitor at the beginning of this study was Mr. Robert Johnson; the current point of contact is John Martin, STEDP-EP-CP.

The work was performed by the Ecological Processes Branch (CN-N) of the Installations Division (CN), U.S. Army Construction Engineering Research Laboratory (CERL). The CERL Principal Investigator was Dr. Alison Hill; Mr. Verl Emrick performed the work. This research was supported in part by an appointment to the Research Participation Program at CERL administered by the Oak Ridge Institute for Science and Education through an interagency agreement between the U.S. Department of Energy and CERL. Dr. Harold E. Balbach is Chief, CECER-CN-N, and Dr. John T. Bandy is Operations Chief, CECER-CN. The technical editor was Gloria J. Wienke, Information Technology Laboratory.

The Director of CERL is Dr. Michael J. O'Connor. 


\section{Contents}

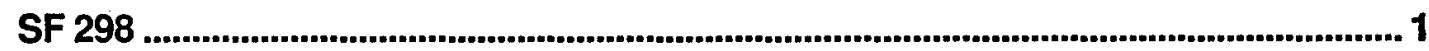

Foreword (.......................................................................................................................... 2

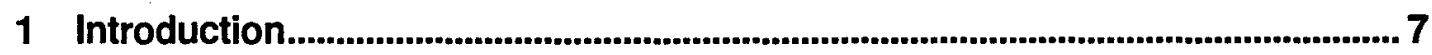

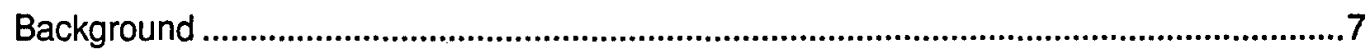

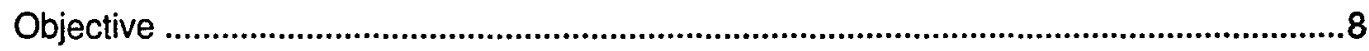

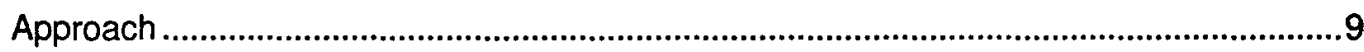

Mode of Technology Transfer .........................................................................................

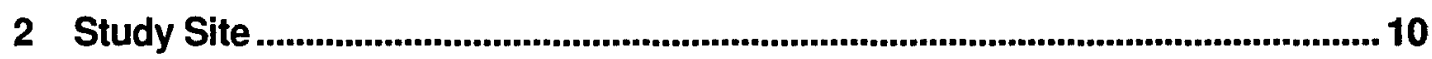

Installation History .................................................................................................10

Physical Setting..................................................................................................10

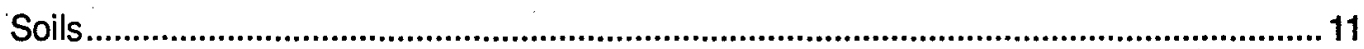

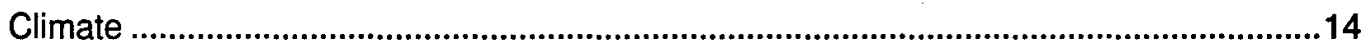

Dugway Proving Ground's Mission ................................................................................14

3 Field Data Collection................................................................................................. 15

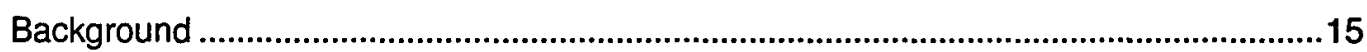

Releve Method at Dugway Proving Ground.................................................................16

4 Classification of Plant Communities ...................................................................... 18

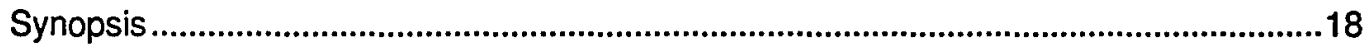

Data Preparation and Reduction ..............................................................................18

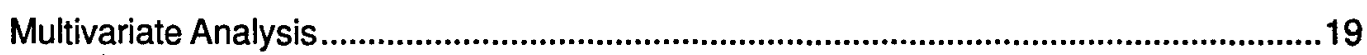

Procedures ......................................................................................................................20

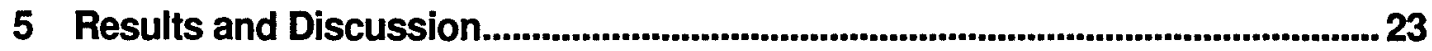

Classification ...........................................................................................................23

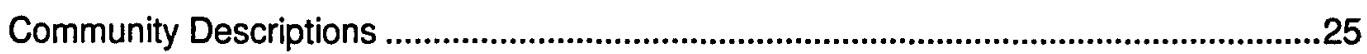

Needle Leaved Evergreen Dwarf Open Woodland Formation..........................................26

Great Basin Arid Shrubland Formation .......................................................................28

Great Basin Cold Desert Chenopod Shrubland Formation................................................34

Great Basin Mixed Shrubland Formation .............................................................................37

Great Basin Cold Desert Grassland Formation .................................................................38 
6 Summary and Conclusions ....................................................................... 41

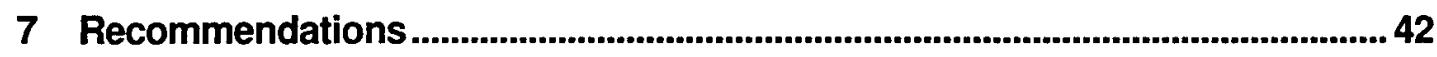

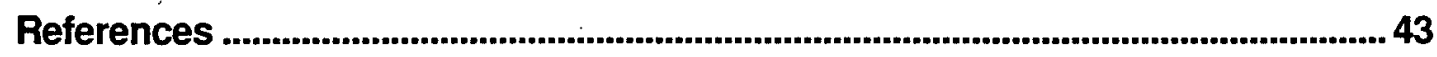

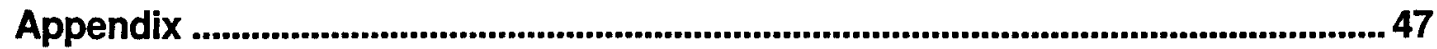

Distribution 


\section{List of Figures and Tables}

\section{Figures}

1 Steps in the landscape-guided approach to vegetation mapping described by

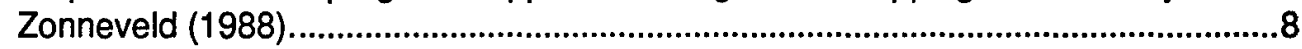

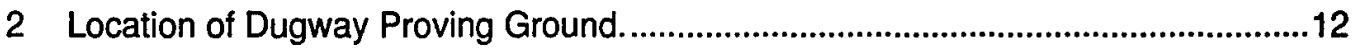

3 Schematic of the steps in the multivariate analysis procedure...............................19

4 Similarity relationship of the identified associations at DPG calculated by MDS. .....21

5 Needle leaved evergreen dwarf open woodland formation....................................26

6 Schematic of the distribution of the identified Utah juniper associations in relation to recognized environmental gradients at Dugway Proving Ground............27

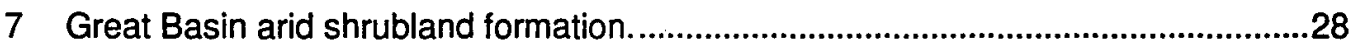

8 Schematic of the distribution of the identified sagebrush associations in relation to recognized environmental gradients at Dugway Proving Ground. ...........29

9 Schematic of three closely related associations distributed along an elevational

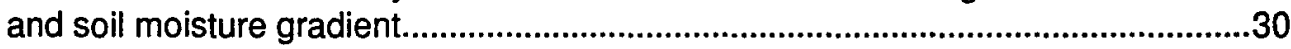

10 Great Basin cold desert Chenopod shrubland formation ......................................34

11 Schematic of the distribution of the Chenopod-dominated associations identified at Dugway Proving Ground in relation to soil salinity and depth to

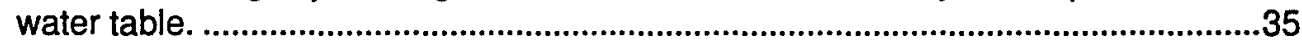

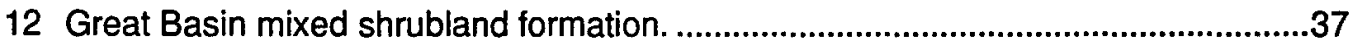

13 Great Basin cold desert grassland formation. ..........................................................38

Tables

1 Major steps in the approach to mapping DPG's vegetation and how

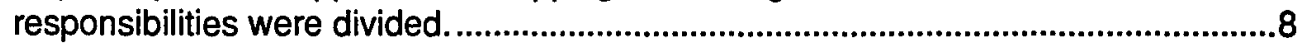

2 Modified Braun-Blanquet cover abundance scale and class midpoints....................17

3 Hierarchical classification and frequency of DPG plant communities. ......................24

4 Other classifications of the associations identified at DPG...................................25

A-1 Mean vegetative cover and constancy of the most common species at DPG in the 26 identified associations and 1 formation at DPG.

A-2 Elevation, slope, and occurrence of the 26 identified associations and 1 formation occurring at DPG 


\section{Introduction}

\section{Background}

In 1996, the natural resource staff at Dugway Proving Ground (DPG), with the assistance of researchers from the U.S. Army Construction Engineering Research Laboratories (CERL), embarked on a project to classify and map the distribution and occurrence of the plant communities occurring at DPG. Classification and mapping are required as part of the Planning Level Survey mandated by Army Regulation 200-3, Natural Resources-Land, Forest and Wildlife Management. The project focused on the actual vegetation rather than potential vegetation. Recent (August 1994) color infrared aerial photography of the entire installation, at a scale of $1: 8,000$, was available to the investigators. Because of this availability, investigators chose to map the vegetative communities at DPG through aerial photo interpretation (API). The vegetation mapping approach chosen was based on the Vegetation Mapping Program of the National Park Service and National Biological Service (currently the Biological Resources Division of the U.S. Geological Service) and closely resembled the landscape-guided approach described by Zonneveld (1988). The essential elements of this approach are API, systematic field sampling, classification of plant communities based on field data, reinterpretation of API, and final mapping and reporting (Figure 1).

The classification of plant communities from data collected in the field is a critical component of the landscape-guided approach to vegetation mapping. Field data can be classified in two different ways: a priori or derived. A priori classification requires the investigator to place surveyed plant communities into previously described classes (Küchler 1988). An a priori classification assumes that all plant communities occurring within the region being studied have been previously identified, described, and integrated into a mutually exclusive system.

Several classification systems were reviewed for possible use in this study. Systems such as: Driscoll et al. (1984), and the Federal Geographic Data Committee's National Vegetation Classification System (1996) did not provide the detail required for this study. Whereas, Shantz (1925); Fautin (1946); Gates, Stoddard, and Cook (1956); Tueller et al. (1979); Blaisdell, Murray, and McArthur (1982); Blaisdell and Holmgren (1984); West (1982, 1988); Bourgeron and Engleking 


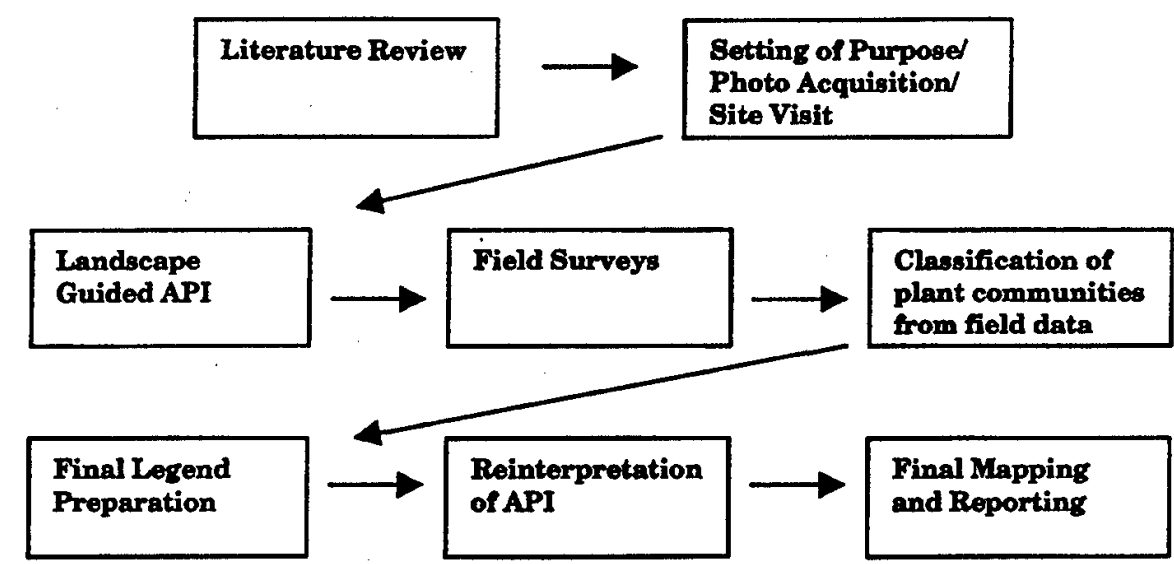

Figure 1. Steps in the landscape-guided approach to vegetation mapping described by Zonneveld (1988).

(1992), among others, were either regional in scope or described specific plant communities for other research purposes. Vest (1962) described the biotic communities of DPG. However, the age of this classification reduced its usefulness. Since an adequate $a$ priori classification was not available, investigators decided to derive the plant community classification for DPG.

\section{Objective}

Classification of DPG's plant communities was part of a larger effort undertaken by CERL and DPG to map and classify the plant communities at DPG (Table 1 adapted from Zonneveld [1988]). Dugway Proving Ground staff were responsible for API, field data collection, and production of final map (steps 3, 4, 7, 8, and 9). CERL's investigators' responsibilities were to derive a plant community classification from field data and report the results of the classification (steps 5 and 6 ).

Table 1. Major steps in the approach to mapping DPG's vegetation and how responsibilities were divided.

\begin{tabular}{|c|c|c|}
\hline Steps & Steps in Mapping Approach & Responsibilities \\
\hline 1 & Study of Literature and References & CERL \\
\hline 2 & Setting of Purpose/Photo Acquisition/Site Visit & DPG/CERL \\
\hline 3 & Landscape Guided API & DPG \\
\hline 4 & Field Survey & DPG \\
\hline 5 & Classification of Plant Communities & CERL \\
\hline 6 & Report on Derived Classification & CERL \\
\hline 7 & Final Legend Preparation & DPG \\
\hline 8 & Reinterpretation of API & DPG \\
\hline 9 & Final Mapping and Reporting & CERL/DPG \\
\hline
\end{tabular}


Overall CERL research objectives were to:

1. Recommend scientifically accepted field data collection methods appropriate for deriving a plant community classification.

2. Use multivariate data analysis techniques to explore the plant community data and derive a detailed hierarchical classification of the plant communities occurring at DPG.

3. Report results.

\section{Approach}

Applicable field methods for collecting plant community data were reviewed in the literature. A proper field method was selected and demonstrated to staff at DPG. Staff at DPG collected field data using the method selected. The data collected by DPG was subsequently analyzed by CERL using several multivariate classification techniques. The results of the multivariate work were interpreted and a hierarchical classification of the identified plant communities developed.

\section{Mode of Technology Transfer}

This report documents: (1) the field data collection methods demonstrated by CERL and used by DPG staff to determine plant community composition, (2) the methods used in deriving a plant community classification, and (3) the results of the classification. Information contained in this report will be used by DPG staff to complete a vegetation map of the installation. Dugway Proving Ground staff will be provided copies of this report and digital copies of the summarized field data in spreadsheet format.

This report is available on the CERL web page at http://www.cecer.army.mil. 


\section{Study Site}

\section{Installation History}

The original 51,303 hectares that comprised DPG were withdrawn from the public domain in early 1942 by order of President Roosevelt. The principal purpose of the installation, which was officially activated 1 March 1942, was to test a variety of bombs, mortars, and chemical weapons for use in World War II. After the end of World War II, DPG was placed on stand-by status and then reactivated in 1950 when an additional 112,955 hectares were added to its boundaries. Additional lands have been acquired throughout the history of DPG, which now occupies approximately 333,000 hectares $\left(4662 \mathrm{~km}^{2}\right)$ or an area about the size of Rhode Island.

\section{Physical Setting}

Dugway Proving Ground is within the Great Basin (GB) physiographic region that encompasses much of Nevada, western Utah, and portions of surrounding states (Fenneman 1931). Physiographically, the GB region is characterized by broad, high elevation valleys separated by mountain ranges as high as $4000 \mathrm{~m}$. The physiography of the GB significantly affects the hydrologic regime of the region. The basin was so named because there is no outlet for surface waters to flow to the sea. Many of the GB valleys have surficial water with no topographic exits; resulting in ephemeral lakes or playas. Evaporation of these ephemeral lakes resulted in the accumulation of salts in many of the soils in the lower elevation valleys of the GB. Holmgren (1983) combined topographic and hydrologic characteristics to recognize two broad types of GB valleys. "Leaky" valleys, or those with underground drainage, may have a water table about $100 \mathrm{~m}$ below the surface. The second are those valleys where there is no underground drainage. In these valleys, the water table is relatively close to the surface.

The complex physiography and hydrology of the GB have resulted in the creation of many steep, interrelated, biophysical gradients that control the distribution of plant communities. The higher mountains typically support coniferous forests, with the intervening valleys supporting either salt desert shrub, or northern desert shrub communities. Salt desert shrub communities are dominated by 
phreatophytic shrubs from the Chenopodiaceae family (Chenopods). The northern desert shrub communities typically are dominated by sagebrush and other shrubs intolerant of saline soils, or Chenopods tolerant of xeric soil conditions (Fautin 1946). The valley's hydrologic character usually dictates which plant communities predominate. In the valleys with adequate drainage, either subterranean or surface, the northern shrub desert tends to be the dominant vegetation type. Valleys without adequate drainage tend to have saline soils and high water tables so salt desert shrub communities dominate on these relatively flat valley floors. Salt desert shrub communities usually give way to northern shrub communities as elevation increases and on benches and alluvial fans.

Dugway Proving Ground is located in northwestern Utah, $75 \mathrm{~km}$ southwest of Tooele and approximately $105 \mathrm{~km}$ southwest of Salt Lake City (Figure 2). It is bordered on the west by the Great Salt Lake Desert. The remaining three sides are bordered by mountain ranges: the Cedar Mountains $(2133 \mathrm{~m})$ to the north, the Davis Mountains (2097 m) to the east, and the Simpson Mountains (2547 m) to the south. Within the broad intervening valleys there are several isolated mountains: Wig Mountain (1573 m), Granite Mountain (2146 m), Camelback Mountain (1667 m), and Simpson Buttes (1643 m) (Vest 1962). The physiography of DPG, tall mountain ranges separated by rolling piedmont and flat plains, is typical of the GB physiographic region. Dugway Proving Ground was inundated by several large lakes during the numerous glacial periods of the Pleistocene, as evidenced by the many terraces that are the remnants of ancient lake shorelines. Vest (1962) reported evidence of six shorelines at DPG. From oldest to youngest these shorelines are: (1) Bonneville (1575 m), (2) Provo (1462 m), (3) Stansbury (1372 m), (4) Dugway (1312 m), (5) Timpie (1286 m), and (6) Modern $(1219 \mathrm{~m})$. These periods of inundation had a tremendous effect on the edaphic pattern at DPG. The halomorphic soils in many lower valleys can be attributed to the disappearance of these lakes as the region became progressively more arid (West 1988).

\section{Soils}

The United States Soil Conservation Service (USSCS 1986, now the Natural Resources Conservation Service) identified 5 broad groups of soils found at DPG.

\section{Playa-Saltair}

Soils in this group are very deep, poorly drained soils and playas occurring on mainly level to nearly level basin floors. As such they are subject to spring flooding. Playa-Saltair soils were formed largely from alluvium and lacustrine 
deposits of silt, sand, and clay. These soils occur at DPG's lowest elevations (1280 to $1303 \mathrm{~m}$ ) and correspond primarily to the Great Salt Lake Desert. PlayaSaltair soils support little vegetation due to their high salt content.

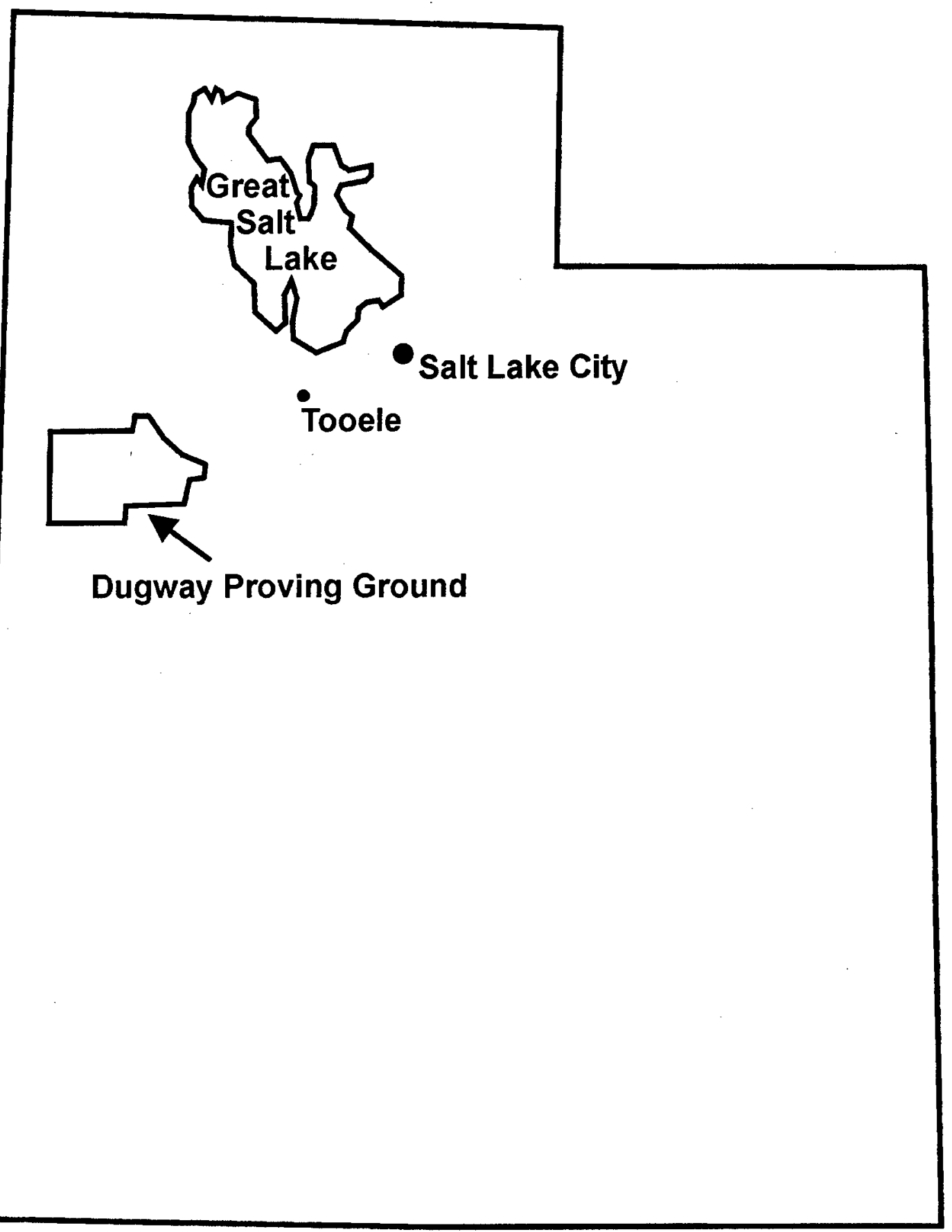

Figure 2. Location of Dugway Proving Ground. 


\section{Skumpah-Skumpah saline-Yenrab}

Soils in this group are very deep, well drained to excessively drained soils that are found on level to moderately sloping low lake terraces. Most of the soils in this group were formed from alluvium, lacustrine deposits, and sands from mixed sources. Skumpah-Skumpah saline-Yenrab soils occur primarily at low elevations at DPG (1293 to $1363 \mathrm{~m}$ ) and support halophytic shrubs. Soil salinity increases with depth in most of the soils within this group.

\section{Mazuma family-Swingler-Bluewing}

The soils in this group are well drained to excessively drained soils on level to moderately sloping lake and fan terraces. Soils in the Mazuma family-SwinglerBluewing group developed from alluvium and lacustrine sediments derived from mixed rock sources. Soils in this group support halophytic shrubs and perennial grasses and generally occur at 1300 to $1363 \mathrm{~m}$. Even though these soils support halophytic shrub communities, the soils are not excessively saline.

\section{Goldrun-Hiko Peak-Heist}

Soils in this group are well drained to excessively drained soils on gently to moderately sloping fan terraces. Goldrun-Hiko Peak-Heist soils have a more complicated pedogenesis than the previous groups. They are derived from a variety of parent material such as lacustrine sands from mixed rock sources, alluvium from mixed rock, and alluvium from igneous rock. Soils in the Goldrun-Hiko PeakHeist group occur between 1333 and $1636 \mathrm{~m}$ elevation at DPG. Because they occur at higher elevations, they receive greater moisture and are classed as semiarid as opposed to the previous groups that are considered arid. Consequently, they support plant communities dominated by juniper and various sagebrushes.

\section{Checkett-Amtoft-Rock Outcrop}

Soils in this group are shallow, well drained to excessively well drained soils on moderately to very steep mountainsides and rock outcrops. Soils in the Checkett-Amtoft group are derived from residuum and colluvium of igneous, metamorphic, and limestone rock. Soils in this group occur from 1333 to $2121 \mathrm{~m}$. Vegetation is typically dominated by juniper and black sagebrush. Rock Outcrop are areas where barren bedrock is exposed, typically on ridgetops and escarpments, and are usually devoid of vegetation. 


\section{Climate}

Dugway Proving Ground is generally considered a cold temperate desert and lies within the Desert Shrub Biome described by Fautin (1946). Though classified as a "cold" desert, DPG and surrounding regions experience wide seasonal and diurnal fluctuations in temperature. Generally, summers are hot in the day and cool at night. The mean maximum temperature for July, at approximately 1300 $\mathrm{m}$, is $34^{\circ} \mathrm{C}$; while the mean minimum temperature is $17^{\circ} \mathrm{C}$. Winter months are cold and experience less diurnal temperature fluctuations than summer months. The mean maximum temperature in January, at approximately $1300 \mathrm{~m}$, is $3^{\circ} \mathrm{C}$; while the mean minimum temperature is $-8^{\circ} \mathrm{C}$. The average frost-free period is between 120 and 160 days on the basin floor and 100 to 140 days in the mountains (USSCS 1986). Precipitation in the basin is fairly evenly distributed throughout the year with a slight peak occurring in mid-late spring. Annual rainfall ranges from 15 to 20 centimeters on the basin floor and low, isolated mountains such as Camelback and Wig, and Simpson Buttes (Vest 1955). The higher mountains (i.e., Cedar Mountains, Granite Mountains) receive up to 40 centimeters of precipitation per year (USSCS 1986). No permanent surface waters occur on DPG, though there are a few perennial springs in the Cedar Mountains and Granite Mountains. Ephemeral streams, such as Government Creek, experience surface flow during occasional intense summer storms and in the spring when runoff from high elevation snowmelt is supplemented by rain events (Stephens and Sumison 1978). Shallow ephemeral lakes and pools occasionally form in the playas at DPG's western end from surface runoff and subsurface flow.

\section{Dugway Proving Ground's Mission}

Dugway Proving Ground is currently part of the U.S. Army Test and Evaluation Command. The primary mission of DPG is to plan, conduct, analyze, and report the results of technical tests and studies; especially in the areas of chemical defense, biological defense, incendiary, smoke and obscurant systems, and environmental technology testing. Dugway Proving Ground also provides test expertise, services, and support for all authorized customers, including the United States and foreign governments and nongovernmental organizations. In addition, DPG is a major Range and Test Facility for chemical and biological defense testing and a Reliance Center for the U.S. Department of Defense. Dugway Proving Ground is also used by the United States Air Force for various testing programs. The Utah National Guard is a tenant organization at DPG. 


\section{Field Data Collection}

\section{Background}

The field data collection methods used for vegetation mapping at DPG were based on phytosociological methods developed in Europe by Dr. Josiah BraunBlanquet. The original purpose of Braun-Blanquet's phytosociological technique was to describe and classify the world's plant communities based on floristic composition, rather than physiognomic structure (Braun-Blanquet 1932). Phytosociology has since been defined as "...the discipline which concerns itself with the study of vegetation as such, with its floristic composition, structure, development and distribution" (Poore 1955).

Braun-Blanquet's field survey methods use a series of subjectively located sample plots, called releves, to describe and classify plant communities (Kent and Coker 1992). According to Dr. Braun-Blanquet there were three basic requirements that each site must meet prior to its selection as a releve site (MuellerDombois and Ellenberg 1974):

1. It should be large enough to contain all species belonging to the plant community.

2. The habitat should be uniform throughout the releve area as far as one can determine this.

3. The plant cover should be as homogeneous as possible.

Once an appropriate site was selected, the size of the releve was determined by the calculation of a species area curve for each site (Bonham 1989). After the releve size and borders were determined, species were listed by height stratum and the amount of aerial vegetative cover for each was visually estimated by using a cover/abundance scale. Before the widespread use of computers, the releve data would be listed in table format and similar samples grouped into associations, based upon their similarity in species composition and abundance (Poore 1955; Mueller-Dombois and Ellenberg 1974). This method, known as association table work, was used extensively in Europe in the first half of the twentieth century. It has proven to be a fairly reliable method of classifying and describing associations when used by experienced workers (Becking 1957; Shimwell 1971; Gauch 1982). 
The original methods developed by Dr. Braun-Blanquet were modified and adapted throughout the twentieth century to meet specific needs of plant ecologists. Recently, phytosociological methods have been used extensively for the purposes of plant community classification and vegetation mapping (The Nature Conservancy 1994a). Excellent reviews of the releve technique, its development and modification, and introduction to North America can be found in Poore (1955), Becking (1957), Shimwell (1971), Mueller-Dombois and Ellenberg (1974), and Kent and Coker (1992).

\section{Releve Method at Dugway Proving Ground}

\section{Season}

The summer of 1996 was originally scheduled for the collection of field data. However, due to unforeseen events, only preliminary data were collected. Nevertheless, valuable initial information was obtained during CERL's initial site visits. During 1996, several species area curves were compiled and a $10-\mathrm{m}$ by $10-\mathrm{m}$ area was identified as the appropriate releve size for characterizing DPG's plant communities. Twenty-seven releves were subsequently placed at a variety of sites representing many of the biophysical gradients at DPG. Analysis of these releves identified several plant formations, alliances, and associations at DPG, and improved subsequent aerial photo interpretation. The preliminary information gained in 1996 offered CERL and DPG staff the opportunity to examine various approaches to mapping DPG's plant communities, and to agree upon the approach best suited to the requirements of DPG.

\section{Season}

Plot Allocation. Based on work in 1996, DPG and CERL staff decided to use the landscape-guided approach (Figure 1) to map DPG's plant communities. The decision to use the landscape-guided approach required a change in the plot allocation procedure, from a subjective plot allocation, to a stratified random procedure. Stratification of the study area was accomplished by: interpreting 1:8000 color infrared (CIR) aerial photographs, delineating individual vegetative polygons, and randomly locating a single releve within each delineated polygon. Once DPG personnel determined that a sufficient number of plots had been located in a particular vegetation type, no further plots were allocated.

Inventory Methods. A $10-\mathrm{m}$ by $10-\mathrm{m}$ releve plot was used to collect data on plant community composition. The releve plot was sampled by the following height categories: $>3$ meters (Tall vegetation stratum), 1 to 3 meters (Medium 
vegetation stratum), and $<1$ meter (Low vegetation stratum). In each of the three height categories each plant was named to species and its aerial vegetative cover visually estimated using a modified Braun-Blanquet cover abundance scale (Table 2). Cover of cryptobiotic crusts, bare soil, and rocks was also visually estimated within the boundaries of the releve plot using the cover classes in Table 2 (from Mueller-Dombois and Ellenberg 1974). Elevation, aspect, and slope were determined for each releve location.

Table 2. Modified Braun-Blanquet cover abundance scale and class midpoints.

\begin{tabular}{|c|c|c|}
\hline Aerial Vegetative Cover & Cover Class & Class Midpoint \\
\hline $95-100 \%$ & 6 & 97.5 \\
\hline $75-95 \%$ & 5 & 85 \\
\hline $50-75 \%$ & 4 & 62.5 \\
\hline $25-50 \%$ & 3 & 37.5 \\
\hline $5-25 \%$ & 2 & 15 \\
\hline $1-5 \%$ & 1 & 2.5 \\
\hline Several, cover less than $1 \%$ & + & 1.0 \\
\hline Rare & $r$ & 0.5 \\
\hline
\end{tabular}




\section{Classification of Plant Communities}

\section{Synopsis}

Plant community classification, at its core, is the grouping of similar assemblages of plant species into classes for the purpose of communication and further study (Whittaker 1973). The goals of the classification were to identify recurring assemblages of plant species and describe the floristic composition of these assemblages. The 472 releves inventoried in the summer of 1997 were used to develop a plant community classification for DPG. The classification of DPG communities was a four-step process.

1. Placement of samples (releves) into one of four physiognomic classes (Dwarf Woodland, Woodland, Shrubland, Herbaceous). These physiognomic classes were derived from the standardized national vegetation classification system (SNVCS) and preliminary field data collected in 1996 (The Nature Conservancy 1994b).

2. Arrangement of the samples into four sample-by-species abundance matrices reflecting the initial physiognomic classification in step 1 .

3. Classification of samples in each physiognomic matrix into community associations through multivariate analysis and association table work.

4. Naming of the community associations based on the framework of the SNVCS and development of association descriptions.

\section{Data Preparation and Reduction}

Raw vegetation data, provided by DPG, were arranged into a single sample-byspecies abundance matrix using the cover class midpoints found in Table 1 as data, with each releve representing a sample (Daubenmire 1959; Gauch 1982; Bonham 1989). The large number of releves (samples) resulted in a large, uninterpretable data matrix. As a result, investigators reduced the data by assigning each sample to one of four physiognomic class categories based upon the SNVCS (The Nature Conservancy 1994b) and preliminary data collected in 1996. This initial physiognomic assignment served to improve subsequent multivariate classification by reducing the statistical "noise" commonly associated with large ecological data sets (Gauch 1982; Krebs 1989). Each sample was assigned to a physiognomic class using the following key: 
1. Juniperus osteosperma over above 2 meters ............................................................... 2

No J. osteosperma cover above 2 meters

2. Crowns widely spaced, cover 10 to $25 \%$ Dwarf Sparse Woodland Crowns not touching, cover 25 to $60 \%$ Dwarf Woodland

3. Woody shrub cover $>10 \%$, under two meters Shrubland

Woody shrub cover $<10 \%$, under two meters Herbaceous

After the initial physiognomic class assignments were made, each matrix was examined. Both woodland classes were combined for the subsequent multivariate classification because of their obvious similarities. As a result, three matrices (combined Woodland, Shrubland, and Herbaceous) were analyzed using multivariate methods.

\section{Multivariate Analysis}

Gauch (1982) recommends the use of nonhierarchical clustering (NHCL) techniques when working with large and/or unfamiliar ecological data for classifying vegetation data. However, NHCL requires the number of clusters be supplied by the investigator. To designate an ecologically realistic number of clusters for the NHCL procedure, two additional multivariate techniques, hierarchical clustering (HCL) and multidimensional scaling (MDS), were used to determine the likely number of clusters within each data matrix. Each of the three physiognomic class sample-by-species data matrices underwent the multivariate analysis separately (Figure 3). Multivariate analysis was performed by Syntax 5.0 (a computer program for multivariate data analysis, Podani 1993).

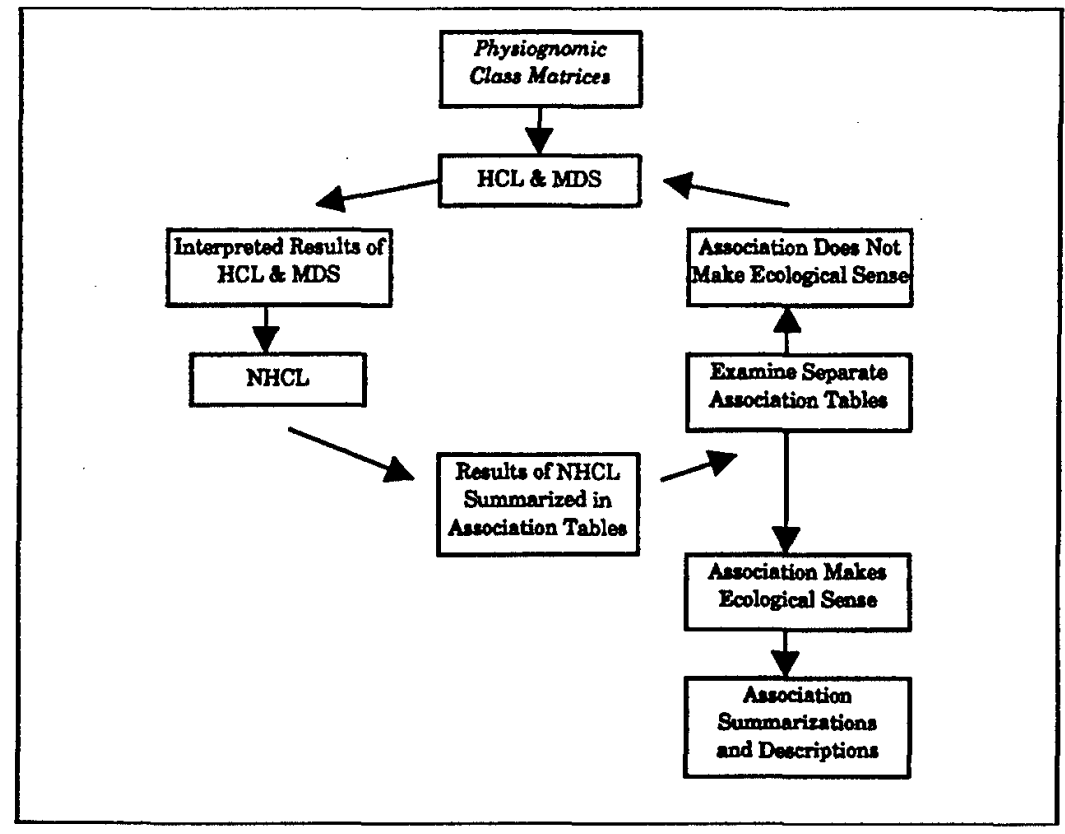

Figure 3. Schematic of the steps in the multivariate analysis procedure. 


\section{Procedures}

\section{Hierarchical Clustering and Multidimensional Scaling}

Sample dissimilarity, using the percentage difference algorithm, was calculated for each physiognomic matrix. The samples were then hierarchically clustered by the unweighted pair-group method using arithmetic averages (van Tongeren 1987). This method of HCL is considered a sound method for the identification of plant communities (Gauch and Whittaker 1981; Gauch 1982; Krebs 1989). Dendrograms of the cluster analysis were generated and interpreted following the suggestions of Faith (1991).

Multidimensional scaling has been found to be a robust method for detecting patterns in community ecology (Minchin 1987; Austin 1991). Multidimensional scaling was also used to further investigate the number of possible clusters in each of the physiognomic data matrices. The percentage difference algorithm was used to calculate sample dissimilarity. The results of the MDS were plotted in a two-dimensional ordination space and the number of obvious groups noted.

\section{Nonhierarchical Clustering}

Nonhierarchical clustering was performed on each physiognomic matrix, with the number of clusters for each based on the results of the HCL and MDS. The percentage difference algorithm was used to calculate species dissimilarity. The NHCL results were summarized in separate Braun-Blanquet association tables, ostensibly representing individual plant associations, and were examined (Mueller-Dombois and Ellenberg 1974; Gauch 1982).

\section{Ecological Sense}

Further refinement of the association tables was deemed necessary in some instances because the cluster did not make ecological sense. For instance, some tables showed combinations of species that had not previously been reported and whose recognized distributions did not overlap. The individual association tables requiring further refinement underwent the same multivariate analysis procedures (Figure 3). The results were interpreted and additional association tables created, reflecting the further refinement. The association tables were reexamined and limited association table work was used to finalize each association table. Each final association table represented a single floristic association at DPG. 


\section{Data Summarizations}

Associations. Once the association tables had been finalized, mean vegetative cover was calculated for each species in the stratum or strata in which it occurred. Species constancy was also calculated for all species in the association tables. Species constancy was defined as number of samples a species occurred in divided by the number of samples in the association (Kent and Coker 1992). A species was considered dominant if it had a constancy of 1.0 and high vegetative cover relative to the other species within the association. The association names were derived from the dominant species in each stratum.

After the floristic composition of each association was determined, MDS was used to examine the similarity relationships between each association (Figure 4. Associations are identified using the first two letters of the genus and species names of the dominant species.). In addition, the frequency of each association (number of plots in each association divided by the total number of plots) was calculated.

\section{Configuration}

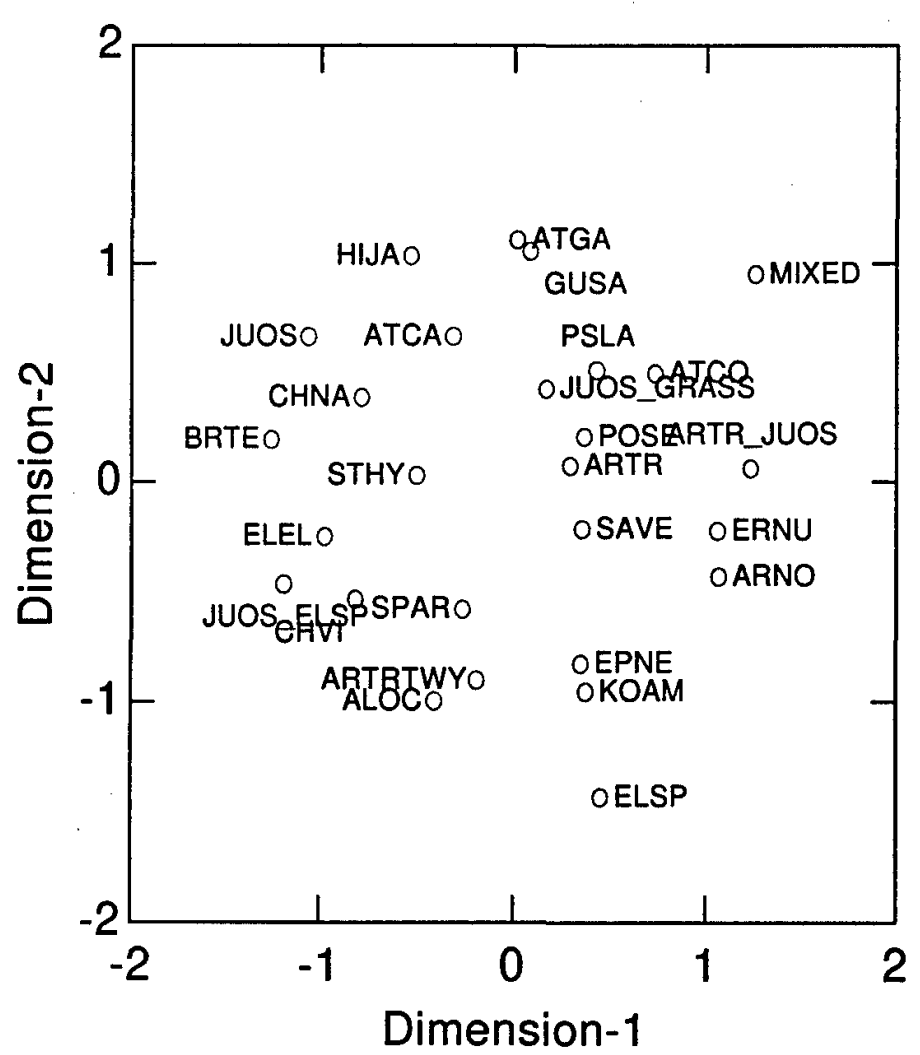

Figure 4. Similarity relationship of the identified associations at DPG calculated by MDS. 
Alliances and Formations. The alliances and formations were derived from the final associations. Since the SNVCS is a hierarchical system, it is possible to derive less detailed levels of the classification system from more detailed levels. Alliances were identified by the genera of the dominant species in the upper most stratum. Formations were named based on environmental and physiognomic characteristics of the floristic associations.

Environmental Relationships. The relationship between the identified community associations and the environment was examined. There was no attempt to directly correlate the distribution of the associations with environmental variables, primarily because detailed edaphic data was not collected. 


\section{Results and Discussion}

\section{Classification}

Table 3 presents the relationship of the identified associations, alliances, formations, and the frequency of each association. Appendix Table A-1 summarizes the dominant species constancy and mean vegetative cover in each association. Appendix Table A-2 summarizes elevation and slope for each of the identified associations.

\section{Formations and Physiognomic Classes}

This study identified four physiognomic classes (dwarf sparse woodland, dwarf woodland, shrubland, and herbaceous) and five formations (Table 3) at DPG. The SNVCS defines physiognomic classes based on vegetative cover at the 5meter level. This definition was adapted from the United Nations Educational, Scientific and Cultural Organization (UNESCO 1973) physiognomic class definition. A strict interpretation of these SNVCS definitions proved ineffective at DPG for identifying woodlands because their short stature would have caused them to be classified as shrublands. This problem with classifying woodlands is common in the western United States (Moir and Carleton 1987). The dichotomous key to physiognomic classes developed in the initial data reduction step attempted to address this problem by defining woodland classes at the 2-meter level.

\section{Alliances}

This study identified 17 alliances at DPG (Table 3). The SNVCS names alliances based on the dominant species in the top most stratum (The Nature Conservancy 1994b). However, most of the associations at DPG were dominated by a single species in a single stratum, resulting in many plant communities having the same alliance and association name. Therefore, alliances were named based on the genera of the dominant species. This naming convention was used by Francis and Aldon (1987) in their approach to classifying semi-arid western plant communities. 


\section{Associations}

This study identified 26 associations at DPG (Table 3). Of these 26 associations, 21 (80 percent) had previously been identified by other authors (Table 4 ).

Table 3. Hierarchical classification and frequency of DPG plant communities.

\begin{tabular}{|c|c|c|c|}
\hline Formation & Alliance & Association & Freq. \\
\hline \multirow[t]{3}{*}{ Needle Leaved Evergreen Dwarf Open Woodland } & Juniperus & $\begin{array}{c}\text { Juniperus osteosperma- } \\
\text { mixed grass }\end{array}$ & 0.06 \\
\hline & & $\begin{array}{c}\text { Juniperus osteosperma- } \\
\text { Elymus spicata } \\
\text { /Artemisia nova }\end{array}$ & 0.04 \\
\hline & & Juniperus osteosperma & 0.03 \\
\hline \multirow[t]{4}{*}{ Great Basin Arid Shrubland } & Artemisia & Artemisia nova & 0.06 \\
\hline & & $\begin{array}{c}\text { Artemisia tridentata Var. } \\
\text { wyomingensis/Poa } \\
\text { secunda }\end{array}$ & 0.01 \\
\hline & & $\begin{array}{l}\text { Artemisia tridentata/ } \\
\text { Juniperus osteosperma }\end{array}$ & 0.01 \\
\hline & & Artemisia tridentata & 0.09 \\
\hline \multirow[t]{6}{*}{. } & Chrysothamnus & $\begin{array}{c}\text { Chysothamnus } \\
\text { viscidiflorus }\end{array}$ & 0.01 \\
\hline & & Chrysothamnus naseosus & 0.01 \\
\hline & Ephedra & Ephedra nevadensis & 0.01 \\
\hline & Gutierrezia & Gutierrezia sarothae & 0.02 \\
\hline & Eriogonum & Eriogonum nummulare & 0.01 \\
\hline & Psoralidium & Psoralidium lanceolatum & 0.01 \\
\hline \multirow[t]{6}{*}{ Great Basin Cold Desert Chenopod Shrubland } & Atriplex & Atriplex confertifolia & 0.04 \\
\hline & & Atriplex canescens & 0.01 \\
\hline & & Atriplex gardneri & 0.00 \\
\hline & Kochia & Kochia americana & 0.03 \\
\hline & Sarcobatus & Sarcobatus vermiculatus & 0.05 \\
\hline & Allenrolfea & Allenrolfea occidentalis & 0.01 \\
\hline Great Basin Mixed Shrubland & & & 0.14 \\
\hline \multirow[t]{7}{*}{ Great Basin Cold Desert Grasslands } & Poa & Poa secunda & 0.00 \\
\hline & Elymus & Elymus elymoides & 0.01 \\
\hline & & Elymus spicatus & 0.02 \\
\hline & Hilaria & Hilaria jamesii & 0.00 \\
\hline & Stipa & Stipa hymenoides & 0.00 \\
\hline & Bromus & Bromus tectorum & 0.23 \\
\hline & Sporobolus & Sporobolus airoides & 0.00 \\
\hline
\end{tabular}


Table 4. Other classifications of the associations identified at DPG.

\begin{tabular}{|c|c|c|c|}
\hline DPG Associations & $\begin{array}{c}\text { Vest's (1962) } \\
\text { Ecological } \\
\text { Communities } \\
\end{array}$ & $\begin{array}{c}\text { Bourgeron and } \\
\text { Engleking's (1992) } \\
\text { Series } \\
\end{array}$ & $\begin{array}{c}\text { Blaisdell et al. (1982); Blaisdell } \\
\text { and Holmgren's (1984) Cum- } \\
\text { munities }\end{array}$ \\
\hline $\begin{array}{c}\text { Juniperus osteosperma- } \\
\text { mixed grass }\end{array}$ & Juniper Brush & Juniperus osteosperma & \\
\hline Juniperus osteosperma & Juniper Brush & Juniperus osteosperma & \\
\hline $\begin{array}{c}\text { Juniperus osteosperma- } \\
\text { Elymus spicatum/Artemisia } \\
\text { nova }\end{array}$ & Pygmy Forest & Juniperus osteosperma & \\
\hline Artemisia nova & & Artemisia nova & Black sagebrush \\
\hline $\begin{array}{c}\text { Artemisa tridentata var. } \\
\text { wyomingensis/Poa secunda }\end{array}$ & & $\begin{array}{c}\text { Artemisia tridentata ssp. } \\
\text { wyomingensis }\end{array}$ & $\begin{array}{c}\text { Wyoming sagebrush/Sandberg's } \\
\text { Bluegrass }\end{array}$ \\
\hline $\begin{array}{c}\text { Artemisia tridentata/Juniperus } \\
\text { osteosperma }\end{array}$ & Mixed Brush & & \\
\hline Artemisia tridentata & & Artemisia tridentata & Big sagebrush \\
\hline Chrysothamnus viscidiflorus & & & Rabbitbrush \\
\hline Chrysothamnus naseousus & & Chrysothamnus naseousus & Rabbitbrush \\
\hline Gutierezia sarothae & & Gutierezia sarothae & \\
\hline Eriogonum nummulare & Vegetated Dune & Eriogonum sp. & \\
\hline Psoralidium lanceolatum & Vegetated Dune & & \\
\hline Atriplex confertifolia & Shadscale-Gray Molly & Artiplex confertifolia & Shadscale-grass \\
\hline Atriplex canescens & & Atriplex canescens & Four wing saltbush \\
\hline Atriplex gardneri & & Atriplex gardneri & Gardner salt bush \\
\hline Mixed Shrub & Mixed Brush & & \\
\hline Ephedra nevadensis & & Ephedra nevadensis & \\
\hline Kochia americana & Shadscale-Gray Molly & & Gray Molly \\
\hline Sarcobatus vermiculatus & Gray Molly Greasewood & Sarcobatus vermiculatus & Greasewood \\
\hline Allenrolfea occidentalis & Pickleweed & Allenrolfea occidentalis & \\
\hline Poa secunda & & Poa secunda & \\
\hline \multicolumn{4}{|l|}{ Elymus elymoides } \\
\hline \multicolumn{4}{|l|}{ Elymus spicatum } \\
\hline Hiliaria jamesii & & Hiliaria jamesii & \\
\hline \multicolumn{4}{|l|}{ Stipa hymenoides } \\
\hline \multicolumn{4}{|l|}{ Bromus tectorum } \\
\hline Sporobolus airoides & & Sporobolus airoides & \\
\hline
\end{tabular}

\section{Community Descriptions}

The composition and ecological relationships of the identified alliances are discussed only in those cases where more than one association was identified within the alliance. Nomenclature follows Welsh et al. (1993). 


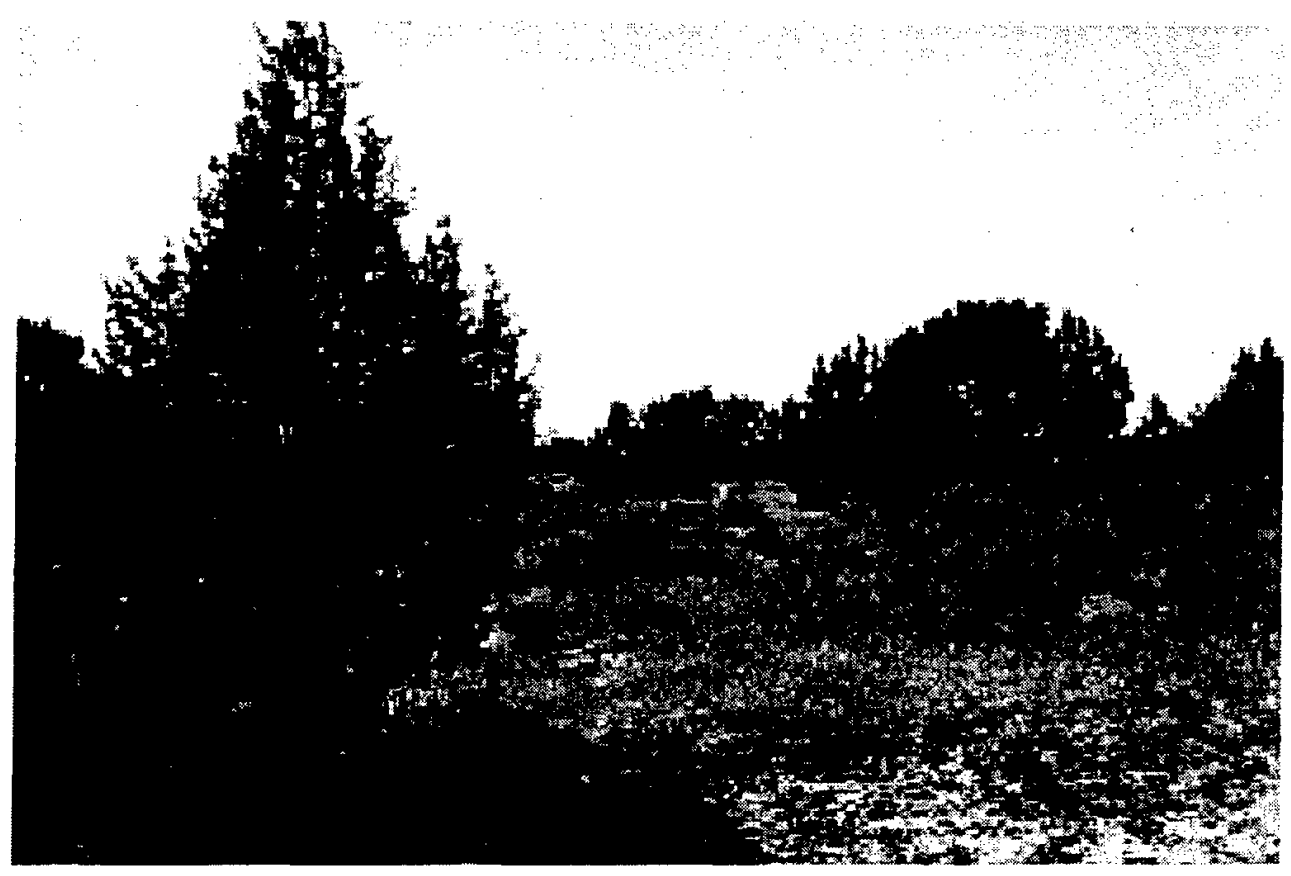

Figure 5. Needle leaved evergreen dwarf open woodland formation.

\section{Needle Leaved Evergreen Dwarf Open Woodland Formation}

\section{Juniperus Alliance}

Throughout most of the Great Basin, Utah juniper (Juniperus osteosperma) cooccurs with pinyon pine (Pinus monophylla) to form a variety of pinyon-juniper associations (West 1988). However, Utah juniper (Juniperus osteosperma), the more xeric of the two (Tueller et al. 1979), was the only tree species found within the boundaries of DPG (not including species planted in the community of Dugway, Utah, and other contonment areas). The taller mountain ranges (i.e., Cedar Mountains and Granite Mountains) located within the boundaries of DPG were blanketed with pygmy Utah juniper woodlands. However, the ameliorating effects that elevation has on climate may not be sufficient to allow the establishment of the slightly more mesic pinyon pine. Utah juniper associations also occur on the undulating sand dunes that occur on the valley floors at DPG. Figure 6 presents the relationship of the three Utah juniper associations to several recognized environmental gradients at DPG (Vest 1962).

Juniperus osteosperma - Mixed Grass Association. The Utah Juniper-Mixed Grass Association was found at elevations ranging from 1403 to $1983 \mathrm{~m}$ with a mean elevation of $1566 \mathrm{~m}$. Slopes ranged from essentially flat to very steep, with a mean slope of 15.6 percent. Utah juniper was the single tree species in this dwarf open woodland association. Total mean cover above $2 \mathrm{~m}$ averaged 12.8 


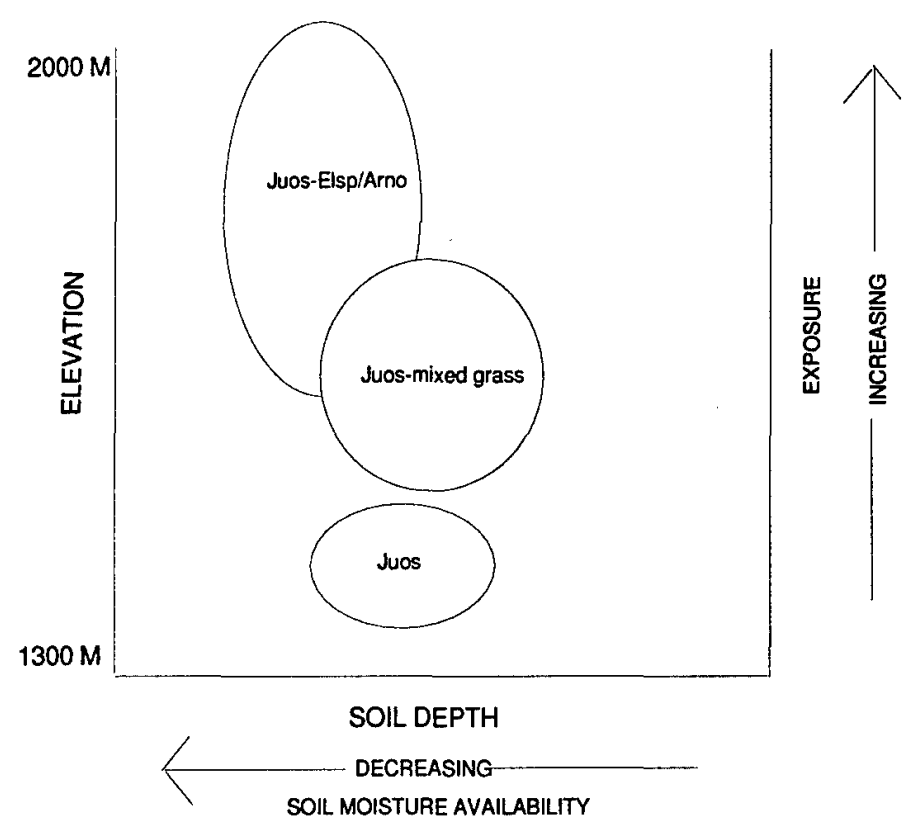

Figure 6. Schematic of the distribution of the identified Utah juniper associations in relation to recognized environmental gradients at Dugway Proving Ground.

percent and ranged from 2.5 to 37.5 percent. Viscid rabbitbrush (Chrysothamnus viscidiflorus) and broom snakeweed (Gutierrezia sarothrae) were common, low cover, shrub associates. There was no single species that dominated the herbaceous strata in this association. Downy brome, with a constancy of 0.8 , was the most common grass associate. Indian ricegrass (Stipa hymenoides), Sandberg's bluegrass (Poa secunda), and bluebunch wheatgrass (Elymus spicata) were other common grass associates.

J. osteosperma - Elymus spicatus/Artemisia nova Association. The Utah JuniperBluebunch Wheatgrass/Black Sagebrush Association occurred in a relatively broad elevation band that ranged from 1418 to $2018 \mathrm{~m}$. The mean elevation $(1581 \mathrm{~m})$ of this association was the highest in the juniper alliance. Slopes ranged from 8 to 35 percent with a mean of 24.4 percent. Floristically and physiognomically, this association was a mosaic of the Utah Juniper-Mixed Grass Association and the Black Sagebrush Association described below. The elevational distributions of the three associations overlapped at DPG (Appendix Table A-2). Based on environmental data and literature reviews, it appears that these associations may be distributed along an available soil moisture gradient. The Utah Juniper-Bluebunch Wheatgrass/Black Sagebrush Association was likely a transitional community between the Utah Juniper-Mixed Grass and Black Sagebrush Associations. Additional information on the edaphic setting of these associations might prove useful in refining the classification. 
The cover of Utah juniper above 2 meters ranged from 2.5 to 15 percent with a mean cover of 4.5 percent. Bluebunch wheatgrass, with a mean cover 9.7 percent, and black sagebrush, with a mean cover 8.5 percent, codominated the low vegetative stratum. Nevada ephedra (Ephedra nevadensis) and viscid rabbitbrush were common, but low cover shrub associates. Sandberg's bluegrass and carpet phlox (Phlox hoodii) were the most common herbaceous associates.

J. osteosperma L. Association. Unlike the previous two Utah juniper associations, this association was found along a relatively narrow elevation band at DPG that ranged from 1346 to $1484 \mathrm{~m}$. The mean elevation (1386 m) was also substantially lower than the other two juniper associations. Slope ranged from 0 to 10 percent with a mean of 3.5 percent. This association occurred primarily on the valley floors at DPG, as indicated by the relatively low mean elevation and slope. Vest (1962) reported that low elevation juniper associations typically were found in and among the many dune systems on the valley floors at DPG. The dune systems provide an edaphic setting that allows Utah juniper to grow below its typical elevational range at DPG.

Utah juniper dominated this association. Cover of Utah juniper ranged from 5 to 62 percent, with a mean cover of 21.5 percent. Downy brome was the most common herbaceous associate with a cover that ranged from 15 to 62 percent and a mean cover of 28 percent. Broom snakeweed and four-wing saltbush (Atriplex canescens) were common low cover shrub associates. Indian ricegrass was a common herbaceous associate.

\section{Great Basin Arid Shrubland Formation}

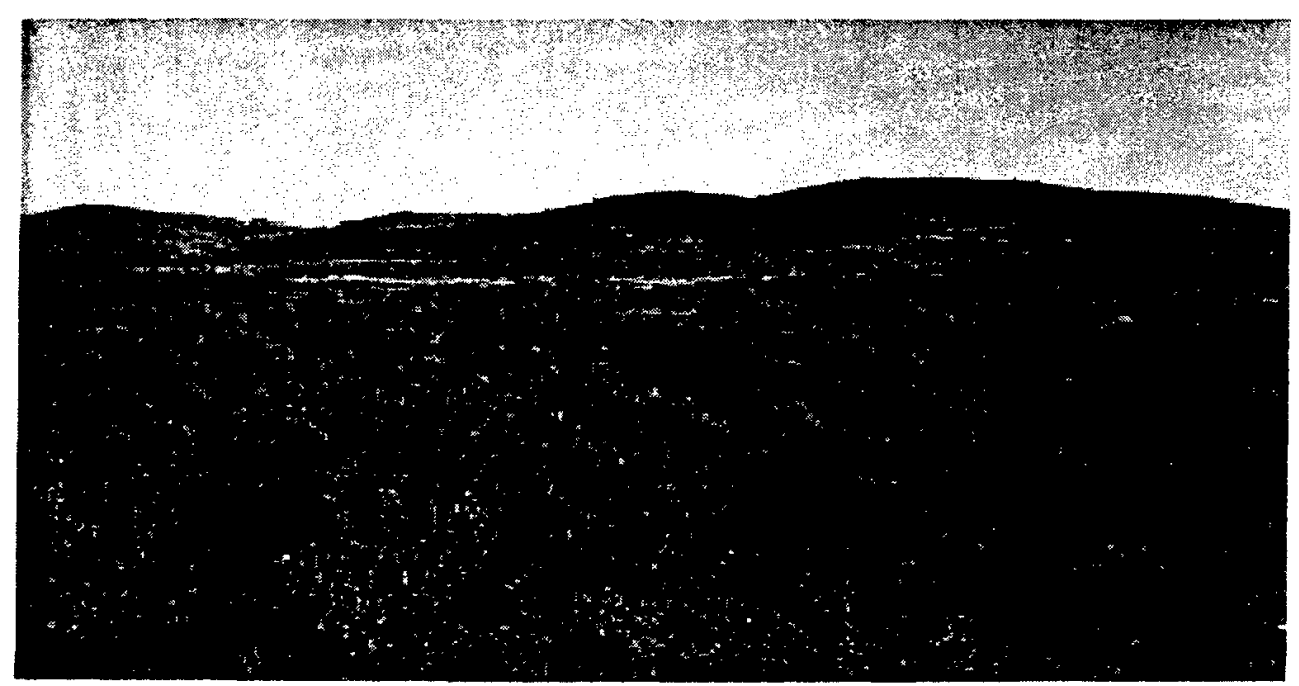

Figure 7. Great Basin arid shrubland formation. 


\section{Artemisia Alliance}

Species of sagebrush (Artemisia) are the characteristic dominant of many communities in the Intermountain West (West 1988). Küchler (1970) and West (1979) recognize two broad sagebrush vegetation types in the western United States: the sagebrush steppe and the Great Basin sagebrush. The sagebrush steppe occurs primarily in the northern Colorado Plateau, Wyoming, Idaho, Oregon, and Washington. The GB type occurs largely in western Utah, Nevada, and northern New Mexico, and is similar to the sagebrush alliance identified at DPG. Physiognomically, the GB sagebrush communities are smaller in stature than the sagebrush steppe, with shrubs rarely attaining a height in excess of 1 meter (West 1988). This assertion was consistent with data collected at DPG. Floristically, diversity is generally lower in the GB sagebrush. West (1988) attributed the physiognomic and floristic differences between the two types to the aridity of the Great Basin. Soil salinity is a critical factor affecting the distribution of sagebrush-dominated communities. Sagebrush does not tolerate high soil salinity and therefore occurs more often in upland areas and foothills throughout the Great Basin (Blaisdell et al. 1982). At DPG there were four associations that comprised the Sagebrush Alliance (Table 3). Figure 8 presents the relationship of the four identified sagebrush associations to several environmental gradients at DPG (Vest 1962).

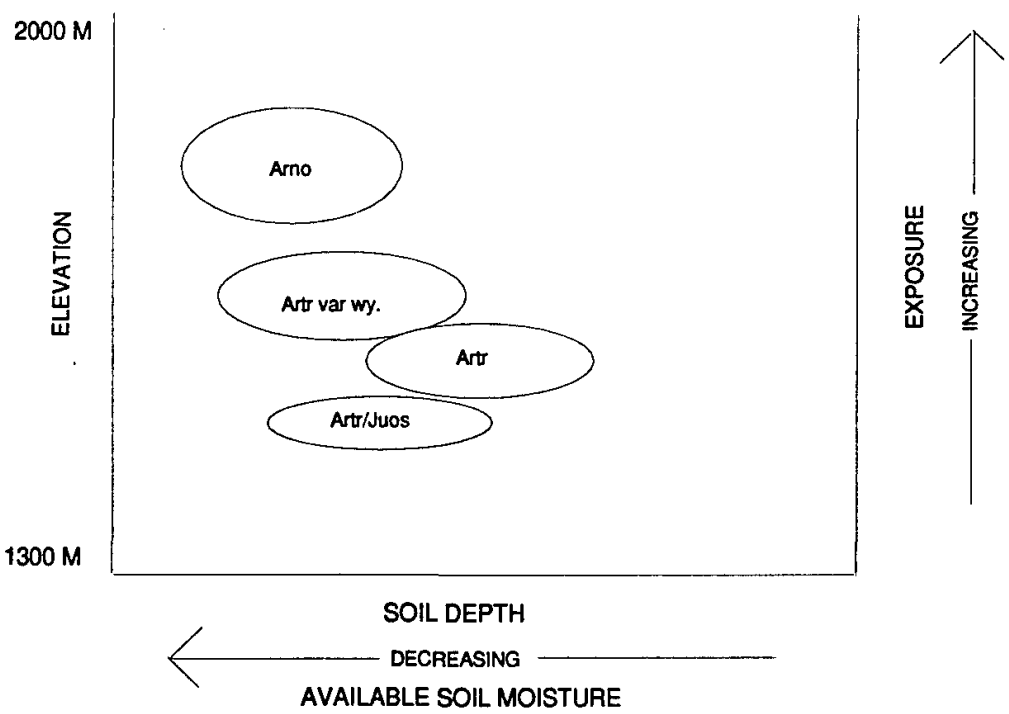

Figure 8. Schematic of the distribution of the identified sagebrush associations in relation to recognized environmental gradients at Dugway Proving Ground. 
A. nova Association. The Black Sagebrush Association occurred in a relatively broad elevational band, ranging from 1431 to $1965 \mathrm{~m}$ at DPG, with a mean elevation of $1644 \mathrm{~m}$. The Black Sagebrush Association was found on slopes that ranged from 0 to 29 percent and was reported to be common on soils in the Checkett-Amtoft group at DPG (USSCS 1986). Black sagebrush has been reported to be associated with shallow, droughty soils (Vest 1962; Beetle 1979; McArthur 1981), and most abundant between $1500 \mathrm{~m}$ and $2400 \mathrm{~m}$ (Blaisdell, Murray, and McArthur 1982).

As previously discussed, the Black Sagebrush Association intergraded with the Utah Juniper-Mixed Grass Association, forming the transitional Utah JuniperBluebunch Wheatgrass/Black Sagebrush Association. Based on literature and environmental data from DPG, it seems likely that the three associations were distributed along a gradient of available soil moisture (Figure 9). The Black Sagebrush Association occurred at the sites with the lowest available soil moisture. The Utah Juniper-Mixed Grass Association occurred at the sites with the highest available soil moisture, and the Utah Juniper-Bluebunch Wheatgrass/Black Sagebrush Association at intermediate sites. Since the Black Sagebrush Association occurred at higher elevations, it would be expected to receive slightly higher moisture, but it typically occurred on more exposed ridges, and northwestern or western exposures. These site conditions lead to shallower soils and more xeric conditions at DPG.

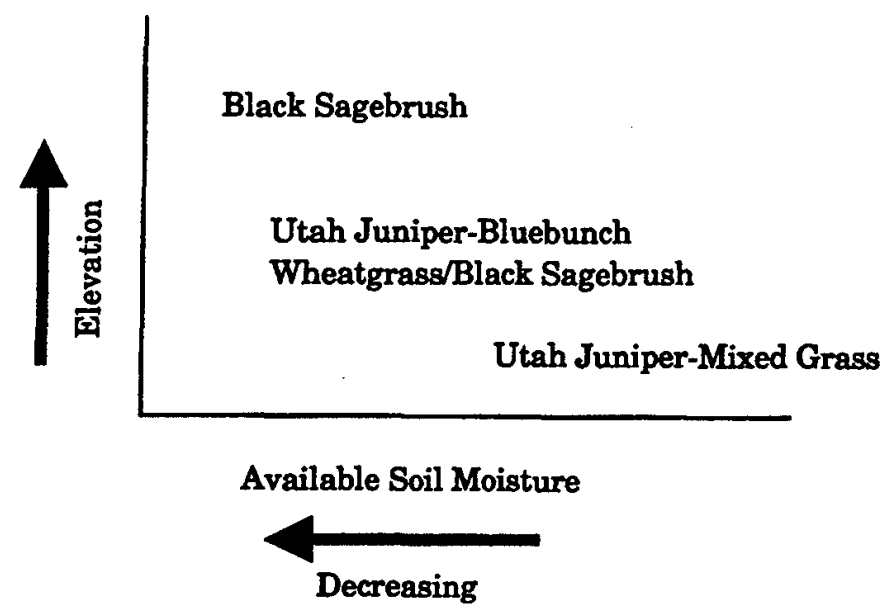

Figure 9. Schematic of three closely related associations distributed along an elevational and soil moisture gradient. 
The cover of black sagebrush, the exclusive dominant, ranged from 15 to 37.5 percent, with a mean cover 24.8 percent. Viscid rabbitbrush and Nevada ephedra were common (constancies of 0.7 and 0.5 , respectively) though relatively low cover shrub associates. Downy brome had a mean cover of 7.3 percent and was a very common herbaceous component (constancy 0.9 ). Sandberg's bluegrass was also a common (constancy 0.8 ) herbaceous component, though its mean cover was considerably lower than downy brome. In their study of habitat type of northern Nevada, Zamora and Tueller (1973) described habitat types in northern Nevada that are very similar in floristic composition to the Black Sagebrush Association.

Artemisia tridentata Var. wyomingensis/Poa secunda Association. The Wyoming Sagebrush (A. tridentata var. wyomingensis)/Sandberg's Bluegrass Association occurred in a narrow (1455 to $1530 \mathrm{~m}$ ) elevational band at DPG, with a mean elevation of $1508 \mathrm{~m}$. Slopes ranged from 16 to 46 percent with a mean slope of 27.6 percent. McArthur (1981) reported that Wyoming sagebrush was usually associated with shallow, poor soils underlain by a caliche or silica layer. At DPG these edaphic conditions usually occur in the foothills and valley outwashes (USSCS 1986). Blaisdell, Murray, and McArthur (1982) reported that Wyoming sagebrush was associated with the most xeric sites of the big sagebrush varieties.

The shrubs Wyoming sagebrush, viscid rabbitbrush, shadscale (Atriplex confertifolia), and Nuttall's horsebrush (Tetradymia nuttalli) all had a constancy of 1.0 in this association. However, Wyoming sagebrush was considered the dominant shrub in this association because it had a mean cover of 33 percent, as opposed to Nuttall's horsebrush, viscid rabbitbrush, and shadscale whose mean covers are 5.0 percent, 1.3 percent, and 1.2 percent, respectively. Sandberg's bluegrass had a mean cover of 11 percent and was the dominant herbaceous species. Downy brome and carpet phlox were both common, low cover herbaceous associates.

Artemisia tridentata Association. The Common Sagebrush Association occurred over a wide elevational range of 1321 to $1860 \mathrm{~m}$, with a mean elevation of 1503 m. Slopes ranged from 0 to 25 percent and had a mean of 4.6 percent. Common sagebrush was typically associated with deep, alluvial soils throughout the Great Basin (Beetle 1979). These sites occur primarily in the alluvial fans of the foothills and piedmont at DPG (USSCS 1986). Common sagebrush (A. tridentata) also occurs on stabilized dunes and lake terraces throughout DPG (Vest 1962).

The cover of the dominant shrub, common sagebrush, ranged from 15 to 62.5 percent (mean 25.1 percent) in this association. Viscid rabbitbrush was a somewhat common (constancy 0.7 ) shrub associate with relatively low cover (mean 1.1 
percent). Downy brome had the highest mean cover (22.9 percent) of the herbaceous species and was the dominant herbaceous species in this association. Indian ricegrass was a somewhat common but low cover herbaceous associate.

A. tridentata/J. osteosperma Association. This association was found from 1455 to $1546 \mathrm{~m}$ at DPG, with a mean elevation of $1498 \mathrm{~m}$. Slopes ranged from 4 to 50 percent with a mean of 19 percent. The identification of the Common Sagebrush/Utah Juniper Association was tentative; it may simply be a variant of the Common Sagebrush Association. However, Moir and Carleton (1987) identified a very similar association. Further investigation of this association is needed to confirm its existence at DPG.

The high constancy (1.0) of Utah juniper distinguishes it from the preceding association, from which it was absent. Nevertheless, Utah juniper had a mean cover of only 2.5 percent, which precluded its designation as a woodland. Common sagebrush was the dominant species (mean cover of 35 percent) in this association. Viscid rabbitbrush had a constancy of 1.0, but relatively low mean cover of 4.5 percent. Downy brome was the dominant herbaceous associate with a mean cover of 19.7 percent. Sandberg's bluegrass was a common (constancy 1.0), though low cover herbaceous associate.

\section{Chrysothamnus Alliance}

Rabbitbrush (Chrysothamnus spp) usually occurred intermixed with sagebrush and halophytic shrub associations. Many species of rabbitbrush are considered less palatable and tend to dominate sites that have been degraded through overgrazing or other destructive land use activities (Blaisdell and Holmgren 1984). This alliance was also common on many of the vegetated dunes throughout DPG.

Chrysothamnus viscidiflorus Association. The Viscid Rabbitbrush Association occurred from 1349 to $1498 \mathrm{~m}$ at DPG with a mean elevation of $1451 \mathrm{~m}$. Slopes range from 0 to 5 percent with a mean of 1.1 percent. Vest (1962) reported that viscid rabbitbrush occupied sandy areas and foothill outwashes. This association tends to intergrade with the Common Sagebrush Association. Viscid rabbitbrush was the exclusive shrub dominant in this association with a mean cover of 15 percent. Downy brome was a common (constancy 1.0), though relatively low cover (mean 5.6 percent) herbaceous constituent. Indian ricegrass was also a common low cover herbaceous associate.

Chrysothamnus nauseosus (Pallas) Association. The Rubber Rabbitbrush Association occurred at elevations ranging from 1424 to $1502 \mathrm{~m}$ with a mean elevation of $1471 \mathrm{~m}$. Physiographically, this association was found in essentially flat areas 
with slopes ranging from 0 to 7 percent. Rubber rabbitbrush (Chrysothamnus nauseosus) and dune rabbitbrush (C. nauseosus var. turbinatus) were the dominant shrubs in this association. Dune rabbitbrush is a variety of rubber rabbitbrush; nevertheless, taxonomists consider it to be a distinctive taxon (Welsh et al. 1993). The two are readily recognizable in situ and often occur as associates. Rubber rabbitbrush had a constancy of 1.0 and mean cover of 16.4 percent, whereas dune rabbitbrush had a constancy of 0.6 and a mean cover of 11.6 percent.

Gutierrezia sarothae Association. The Broom Snakeweed Association generally occurred at the lower elevations of DPG ranging from 1321 to 1497 with a mean elevation of $1375 \mathrm{~m}$. The slope ranges from 0 to 25 percent with a mean of 4.7 percent. Broom snakeweed was the dominant shrub in this association, ranging in cover from 15 to 37.5 percent with a mean of 17.3 percent. Broom snakeweed responds well to disturbance and can dominate on sites that have been degraded (Welsh et al. 1993). No other shrub associates had meaningful cover or constancy in this association. Downy brome was a recurring herbaceous associate (constancy 0.9 ) with relatively high cover of 19 percent. Indian rice grass was also a somewhat common, albeit low cover herbaceous associate.

Eriogonum nummulare Association. The Coin Buckwheat Association occurred between 1317 and $1424 \mathrm{~m}$ elevation at DPG. The mean elevation was $1370 \mathrm{~m}$. The slope ranges from 0 to 10 percent with a mean of 3.5 percent. This association was dominated by the subshrub coin buckwheat (Eriogonum nummulare), which had a mean cover of 11.9 percent. Coin buckwheat typically occurs on stabilized sand dunes throughout much of Western Utah and Nevada (Welsh et al. 1993). Dune scurfpea (Psoralidium lanceolatum) was a common (constancy 0.8) associate having a mean cover of 5 percent. Downy brome and indian ricegrass were also common herbaceous associates, both having constancies of 1.0 and mean covers of 10.1 percent and 1.4 percent, respectively.

Psoralidium lanceolatum Association. The Dune Scurfpea Association occurred from 1314 to $1490 \mathrm{~m}$ with a mean elevation of $1395 \mathrm{~m}$. The slope ranged from 0 to 10 percent with a mean slope of 3 percent. Dune scurfpea was the dominant species in this association and had a mean cover of 18.1 percent. Indian ricegrass was a common (constancy 1.0) herbaceous associate, with a relatively low mean cover of 1.4 percent. Wild tarragon (Artemisia dranunculus) had a high mean cover (18.1 percent), but occurred haphazardly throughout this association (constancy 0.5 ).

Ephedra nevadensis Association. The Nevada Ephedra Association occurred between 1434 and $1825 \mathrm{~m}$, with a mean of $1558 \mathrm{~m}$. The slopes ranged from 0 to 8 
percent, with a mean of 5 percent. Nevada ephedra had a mean cover of 20.6 percent and dominated this association. Common sagebrush was the only common (constancy 1.0) shrub associate. Downy brome was the dominant herbaceous associate with a mean cover of 38.8 percent. Indian ricegrass was a common (constancy 0.8 ) herbaceous associate with a mean cover of 1.1 percent.

\section{Great Basin Cold Desert Chenopod Shrubland Formation}

The GB Cold Desert Chenopod Shrubland Formation was comprised of four alliances and six associations dominated by phreatophytic shrubs in the Chenopodiaceae family. This formation is similar to the saltbush-greasewood type described by West (1988). Salt desert scrub is a common name often used to describe Chenopod-dominated communities in the Great Basin. As the common name implies, these communities often occur on soils that are slightly to very saline, However, Chenopod-dominated communities also occur on non-saline soils where climatic conditions are too xeric to support sagebrush communities (Holmgren 1983). The distribution of Chenopod communities has been related to tolerance to flooding and poor soil aeration, water table depth, and soil texture (Roundy, Evans, and Young 1983). Therefore, the presence of a Chenopoddominated community at a site does not necessarily imply saline soil conditions. Many valley bottoms within the GB are a mosaic of Chenopod-dominated associations. The associations are typically dominated by a single shrub species and are segregated based on edaphic conditions (Figure 11).

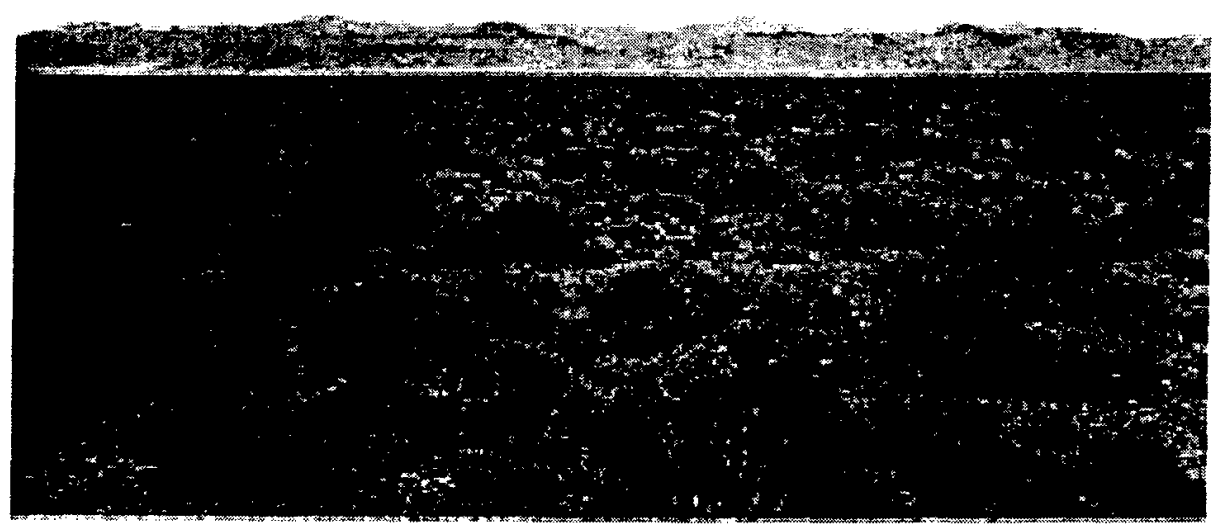

Figure 10. Great Basin cold desert Chenopod shrubland formation. 


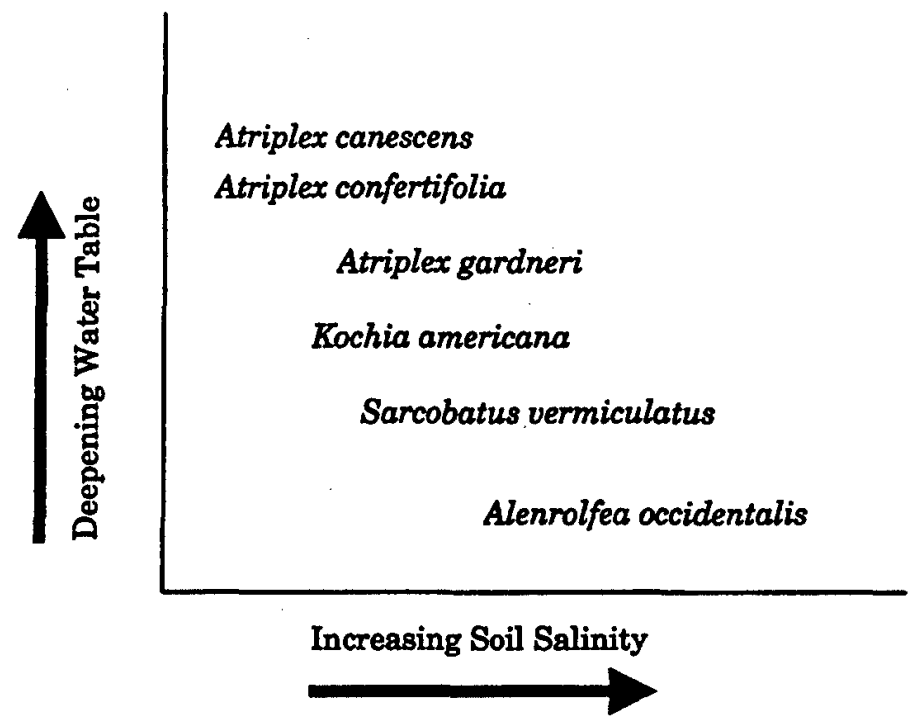

Figure 11. Schematic of the distribution of the Chenopod-dominated associations identified at Dugway Proving Ground in relation to soil salinity and depth to water table.

\section{Atriplex Alliance}

Three associations comprised the Atriplex alliance at DPG.

Atriplex confertifolia Association. The Shadscale Association occurred at DPG from 1342 to $1503 \mathrm{~m}$. The mean elevation $(1438 \mathrm{~m}$ ) was the highest of the three identified Atriplex associations. Blaisdell and Holmgren (1984) report shadscale communities typically occurring in valley bottoms on deep, well drained soils of intermediate salt content. The slope ranged from 0 to 25 percent with a mean of 2.1 percent. Shadscale was the dominant shrub in this association. Vegetative cover of shadscale ranged from 15 to 62.5 percent, with a mean cover of 28.3 percent. Downy brome was the dominant herbaceous associate with a mean cover of 27.5 percent. Squirrel tail (Elymus elymoides) was a common (constancy 0.9) herbaceous associate with a mean cover 1.2 percent.

Vest (1962) reported that shadscale was dominant in three ecological communities at DPG: shadscale-budsage, shadscale-gray molly (Kochia americana)greasewood (Sarcobatus vermiculatus), and shadscale-gray molly. This study identified three similar associations that were dominated by a single Chenopod shrub. Shadscale was dominant only in this association. The other two, the gray molly and greasewood associations, are discussed below. 
Atriplex canescens Association. The Fourwing Saltbush Association occurred at elevations ranging from 1320 to $1483 \mathrm{~m}$ at DPG. The mean elevation was 1418 $\mathrm{m}$. Slope ranged from 0 to 4 percent with a mean of 1 percent. Fourwing saltbush is often associated with sandy soils, but does occur on soils with high clay and silt content (USSCS 1986). Within the Great Basin, this association often occurs in a mosaic with the shadscale and greasewood associations (Blaisdell and Holmgren 1984). Within these mosaics, ecotones between each association were mixtures of several species with no single dominant. These broad zones were often classified in the mixed shrub association described below.

Fourwing saltbush was the dominant shrub in this association with a mean cover of 13.2 percent. Downy brome was the dominant herbaceous associate with a mean cover of $\mathbf{2 1 . 2}$ percent. Pale evening primrose (Oenothera pallida) and indian ricegrass were common (constancy 0.7 ) herbaceous associates, with mean covers of 3.4 percent and 3.1 percent, respectively.

Atriplex gardneri Association. The Gardner's Saltbush Association occurred at DPG on the level plains in the valley bottoms at low elevations $(1415 \mathrm{~m})$. This association was dominated by Gardner's saltbush (Atriplex gardneri) which had a mean cover of 15.0 percent. Shadscale and gray molly were common, low cover shrub associates. Herbaceous associates included: downy brome, Sandberg's bluegrass, and bur buttercup (Ranunculus testiculatus), though each had cover of less than 2 percent.

The Gardner's Saltbush Association was found at only two sites at DPG. Bourgeron and Engleking (1992) have identified an A. gardneri series and its composition has been described by Blaisdell and Holmgren (1984). However, further investigation is needed to understand the distribution of the Gardner's Saltbush Association at DPG.

Kochia americana Association. The Gray Molly Association was distributed in two distinct elevational bands at DPG. The high elevation band occurred from 1966 to $2036 \mathrm{~m}$ and the low elevation band from 1322 to $1574 \mathrm{~m}$. Slope was minimal to nonexistent in this association. Gray molly has been reported to be associated with fine texture soils with little or no gravel (Blaisdell and Holmgren 1984). Gray molly was the single dominant in this association and had a mean cover of 18.0 percent. Greasewood and shadscale were common shrub associates with mean covers of 3.5 percent and 1.3 percent, respectively. Downy brome was the only common herbaceous associate.

Sarcobatus vermiculatus Association. The Greasewood Association occurred in two distinct elevational zones at DPG. The low elevational zone ranges from 
1307 to $1473 \mathrm{~m}$ (mean of $1405 \mathrm{~m}$ ); the high elevation zone ranges from 1571 to $2078 \mathrm{~m}$ (mean of $1926 \mathrm{~m}$ ). Slope ranged from 0 to 4 percent in the low elevation zone. There was no slope on the high elevation sites. The greasewood community that Vest (1962) identified at DPG was found on deep soils made of lake deposits. Greasewood had a mean cover of 17.8 percent and was the single dominant shrub in this association. Downy brome was a common herbaceous associate with a mean cover of 19.4 percent.

Allenrolfea occidentalis Association. This association occurred on the flat valley floors at the lowest elevations (mean $1313 \mathrm{~m}$ ) and therefore under the most saline soil conditions at DPG. Iodine bush (Allenrolfea occidentalis) had a mean cover of 5.3 percent and was the dominant species in this sparsely vegetated association.

\section{Great Basin Mixed Shrubland Formation}
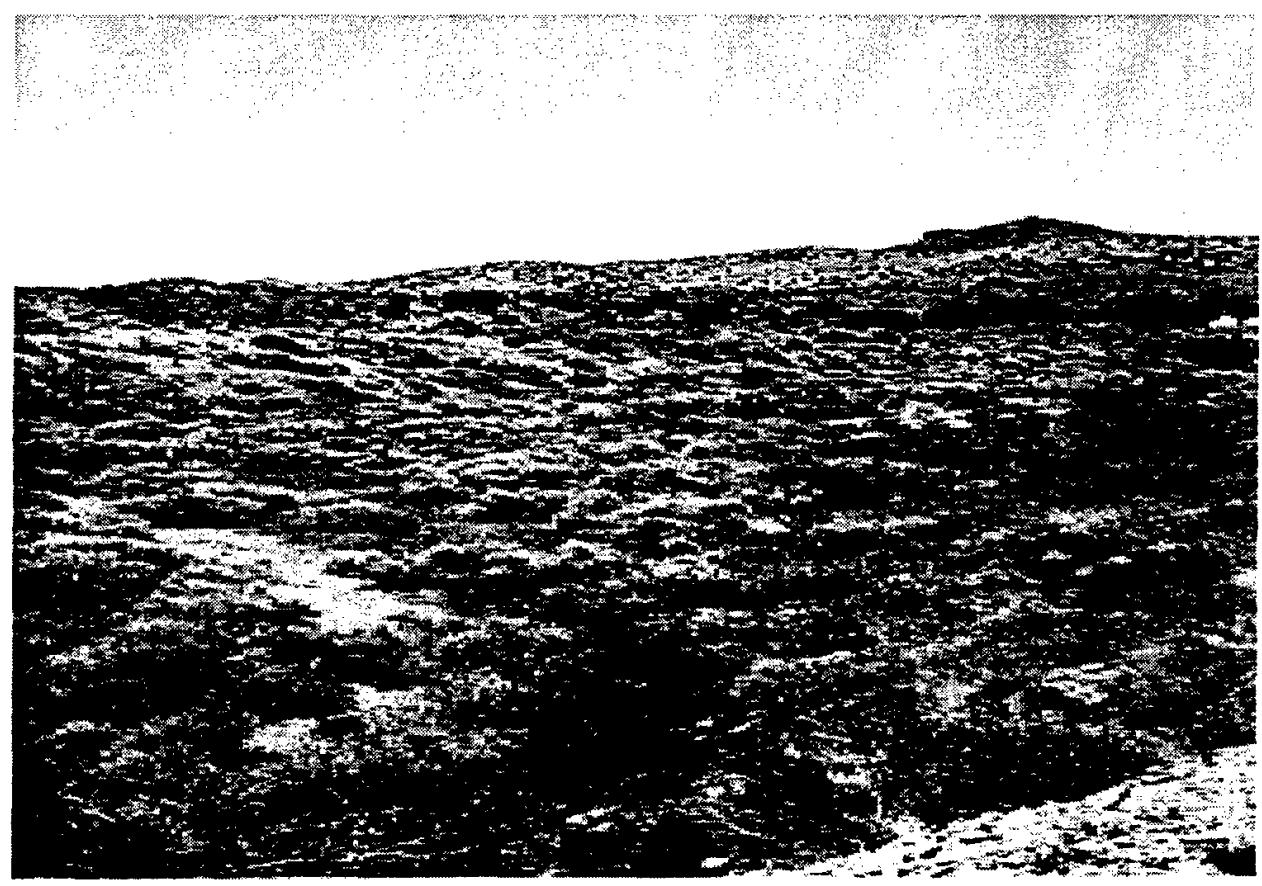

Figure 12. Great Basin mixed shrubland formation. 
Many of DPG's shrub communities were mixtures of species with no particular species being dominant. Vest (1962) described a similar mixed brush community at DPG that had no clear dominant. These mixed shrub communities were placed in the Great Basin Mixed Shrubland Formation. In many cases, these communities were transition zones or ecotones between associations previously described. The Great Basin Mixed Shrubland Formation occurred on a wide range of elevations (1304 to $1793 \mathrm{~m}$ ), though more often at the low to mid elevations. Mean elevation was $1434 \mathrm{~m}$ and slopes ranged from 0 to 45 percent with a mean of 3.2 percent. Broom snakeweed and viscid rabbitbrush were the most common shrubs; both had a constancy of 0.6 . Other common shrubs were: shadscale (constancy 0.5), fourwing saltbush (constancy 0.4), and gray molly (constancy 0.4 ). Vegetative cover of all shrubs was low. Downy brome was the most common herbaceous species (constancy 0.9 ) followed by indian ricegrass (constancy 0.7 ). As with the shrubs, cover of any one herbaceous species was generally low.

\section{Great Basin Cold Desert Grassland Formation}

Poa secunda Association. This association was found on only two sites at DPG: a valley bottom ( $1356 \mathrm{~m}, 0$ percent slope) and a mid elevation $(1510 \mathrm{~m}, 61$ percent slope) site. As a result, this association requires additional investigation to confirm its existence and distribution at DPG. Sandberg's bluegrass, with a constancy of 1.0 and mean cover of 15.0 percent, was the dominant species in this

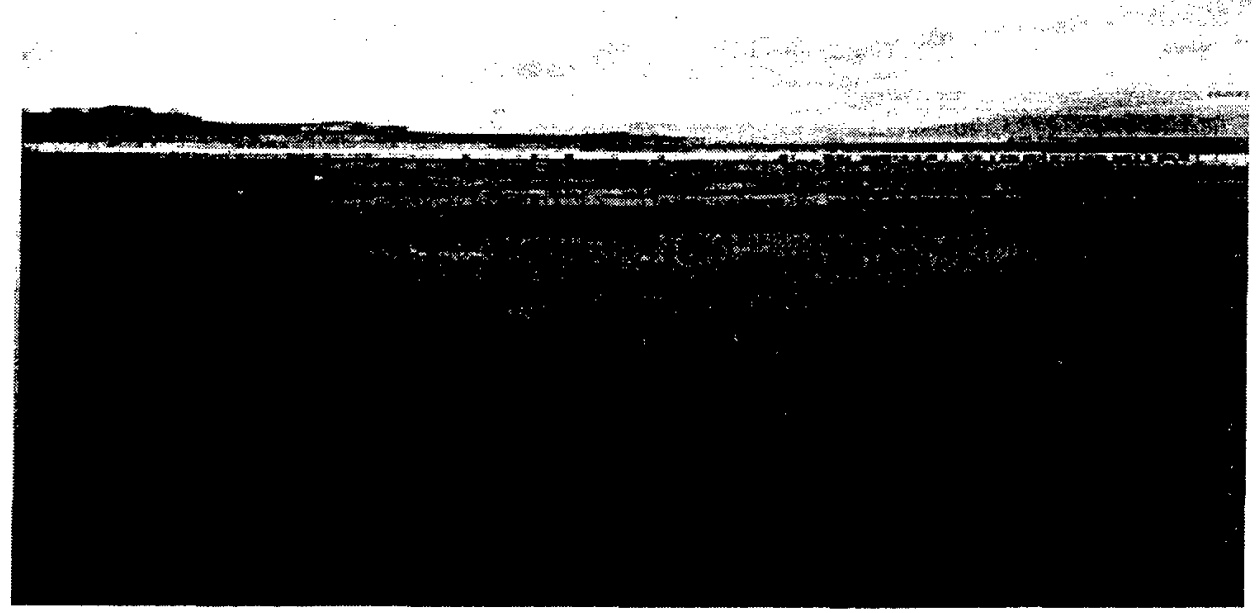

Figure 13. Great Basin cold desert grassland formation. 
grassland association. Shadscale was a common (constancy 1.0), though low cover (mean 1.8 percent) shrub. Downy brome was the most common herbaceous associate.

Elymus elymoides Association. This grassland association ranged in elevation from 1388 to $1498 \mathrm{~m}$ at DPG. Slopes ranged from 0 to 6 percent with a mean of 2.8 percent. This sparsely vegetated association is dominated by squirrel tail and downy brome. Overall vegetative cover was low compared to other associations in the Great Basin Cold Desert Grassland Formation. Shrub cover was sparse to nonexistent. Squirrel tail had a mean cover of 2.5 percent, whereas downy brome had a mean cover of 2.1 percent. Indian ricegrass was the only moderately common (constancy 0.5 ) herbaceous associate.

Elymus spicatus Association. The Bluebunch Wheatgrass Association was the most common native grassland association encountered in this study at DPG. It ranged in elevation from 1482 to $1679 \mathrm{~m}$ (mean of $1556 \mathrm{~m}$ ), and occurred on moderate to steep slopes ranging from 15 to 34 percent (mean 27.8 percent). Bluebunch wheatgrass dominated this association with a constancy of 1.0 and a mean cover of 15.0 percent. However, there was a significant shrub component comprised of three shrubs: shadscale (constancy 0.8 ; mean cover 0.8 percent), viscid rabbitbrush (constancy 0.8 ; mean cover 0.9 percent), and black sagebrush (constancy 0.8 ; mean cover 12.5 percent).

The Bluebunch Wheatgrass Association closely resembled the Black Sagebrush Association described previously. Its relatively high cover and herbaceous dominance of bluebunch wheatgrass was the key feature that differentiated it from the Black Sagebrush Association. Further investigation may result in the identification and classification of an additional association in the Artemisia alliance, the Black Sagebrush/Bluebunch Wheatgrass Association.

Hilaria jamesii Association. This grassland association was dominated by the warm season grass $H$. jamesii (galleta), which had a constancy of 1.0 and a mean cover of 26.3 percent. Downy brome was the most common herbaceous associate (constancy 1.0) with a mean cover of 19.3 percent. Vest (1962) stated that galleta was common in the foothills and lower mountain slopes at DPG. Data from this study indicated that galleta was common in lower elevation sites. The Galleta Grassland Association was encountered at only two sites. Elevation was $1310 \mathrm{~m}$ and both sites were on flat valley bottoms. Further investigation into the distribution of galleta grasslands would benefit the DPG classification.

Stipa hymenoides Association. This grassland association was dominated by indian ricegrass, which had a mean cover of 15.0 percent. Other common 
associates, all with a constancy of 1.0 , were Sandberg's bluegrass, squirrel tail, and downy brome. The Indian Ricegrass Grassland Association was encountered at only two sites; therefore, it is in need of further investigation to confirm its existence and distribution at DPG. The mean elevation and slope were $1545 \mathrm{~m}$ and 25.5 percent, respectively.

Bromus tectorum Association. This association ranged in elevation from 1306 to $1866 \mathrm{~m}$ (mean $1423 \mathrm{~m}$ ) the largest continuous elevational band of all associations identified at DPG. Slopes ranged from 0 to 40 percent (mean 3.7 percent), which was also the largest range of any associations at DPG. The Downy Brome Association was encountered at more sites than any other association at DPG. Cover ranged from 15.0 to 97.5 percent, depending on the site. Downy brome occurs in virtually all associations at DPG. The sites classified as Downy Brome Associations had virtually no other species with cover more than 1.0 percent.

Downy brome, also known as cheatgrass, was believed to have been introduced into the United States around 1870. Downy brome is an annual invasive, nonnative grass that can in many instances replace native vegetation. Downy brome now dominates vast areas of rangeland in the Intermountain West by outcompeting native grasses. Downy brome usually germinates in the fall and completes its life cycle in late June or early July (West 1988). Furthermore, downy brome increases the fuel load, which results in an increase in the fire frequency. The increased fire frequency kills many of the native shrubs and herbs, thereby increasing the available habitat for downy brome. This cycle repeats itself until many sites are almost exclusively dominated by downy brome. The large tracts of land that are exclusively downy brome at DPG were likely formed in this manner.

Sporobolus airoides Association. This grassland association was dominated by $S$. airoides (alkali saccoton) which had a mean cover of 37.5 percent. As its common name implies, alkali saccoton is most often found at DPG and elsewhere, in saline meadows, alkaline sand dunes, and alkali flats where it sometimes forms monospecific communities (Blaisdell and Holmgren 1984; USSCS 1986). Bourgeron and Engelking (1992) recognize a $S$. airoides series in their Western United States Classification System. Vest (1962) reported that alkali saccoton was most abundant in alkaline sandy loams adjacent to dunes at DPG. The Alkali Saccoton Grassland Association was encountered at only two sites. More information on its distribution would improve the DPG classification. Neither elevation nor slope data was available from either site. 


\section{Summary and Conclusions}

Four physiognomic classes, 5 formations, 17 alliances, and 26 associations were identified at DPG. See Table 3 for the names of the types. Most of the associations at DPG were dominated by a single species in a single stratus, resulting in many plant communities having the same alliance and association name.

A majority of the associations identified at DPG ( 80 percent) had been identified by other authors (Table 4). The most common association at DPG was the Downy Brome Association. The land covered by downy brome is expected to increase because of the increased frequency of range fires at DPG. Conversely, the extent of associations dominated by Artemisia species is expected to decline because of the increased fire frequency. Artemisia is a species that is particularly sensitive to fire.

The SNVCS framework proved unsatisfactory for classifying DPG's Juniperus woodlands, a common vegetation type found throughout the installation. A strict interpretation of the SNVCS definition proved ineffective at DPG for identifying woodlands. DPG's short stature woodlands caused them to be incorrectly classified as shrublands so investigators worked around this problem by using a key that defined woodlands at the 2-meter level. Other authors (e.g., Moir and Carleton 1987) have found similar classification problems with short stature woodlands of the western United States. Additional edaphic information on these associations might also prove useful in refining the classification. 


\section{Recommendations}

Five associations of the 26 associations had a low sample size. Four of these associations, the Hilaria jameii, Poa secunda, Stipa hymenoides, and the Sporabolis airoides Associations, are in the Great Basin Cold Desert Grasslands Formation and one, the Atriplex gardneri Association, is in the Great Basin Cold Desert Chenopod Shrubland Formation. Additional investigations to increase sample size and examine edaphic conditions may be in order to better understand the distribution of these communities at DPG.

Additional edaphic information would be useful in several associations, including the J. osteosperma-Elymus spicatus/Artemisia nova Association.

This document and classification will serve DPG well. The classification scheme will be useful for DPG's decision making in environmental and land management planning.

The SNVCS should be tested at other military installations to determine the fitness of the classification scheme and hierarchy. Installations in the western United States would be prime candidates for this additional testing. 


\section{References}

Army Regulation 200-3, Natural Resources-Land, Forest and Wildlife Management, HQDA, 28 February 1995.

Austin, M.P. (1991). "Vegetation, Data Collection and Analysis." In: Nature conservation: cost effective biological surveys, Commonwealth Scientific and Industrial Research Organization, pp 37-41.

Becking, R.W. (1957). "The Zurich-Montpellier School of Phytosociology." The Botanical Review XXIII(7), pp 411-488.

Beetle, A.A. (1979). “Autecology of Selected Woody Sagebrush Species.” In: The Sagebrush Ecosystem: A Symposium. Utah State University, College of Natural Resources: Ogden, Utah.

Blaisdell, J.P., R.B. Murray, and E.D. McArthur. (1982). "Managing Intermountain RangelandsSagebrush-Grass Ranges." U.S.D.A. Forest Service General Technical Report: INT-134. Intermountain Forest and Range Experiment Station, Ogden, Utah.

Blaisdell, J.P., and R.C. Holmgren. (1984). "Managing Intermountain Rangelands-Salt Desert Shrub Ranges." U.S.D.A. Forest Service General Technical Report: INT-163. Intermountain Forest and Range Experiment Station, Ogden, Utah.

Bonham, C.D. (1989). Measurements for Terrestrial Vegetation. John Wiley and Sons, New York.

Bourgeron, P.S., and Lisa Engelking. (1992). "Preliminary Compilation of a Series Level Classification of the Vegetation of the Western U.S. Using a Physiognomic Framework," Idaho Cooperative Fish and Wildlife Research Unit, University of Idaho, Moscow, ID.

Braun-Blanquet, J. (1932). "Plant Sociology: the Study of Plant Communities (English translation)." McGraw Hill, New York, New York.

Daubenmire, R. (1959). "A Canopy-Coverage Method of Vegetational Analysis," Northwest Science 33, pp 43-64.

Driscoll, R.S., D.L. Merkel, D.L. Radloff, D.E. Snyder, and J.S. Hagihara. (1984). "An Ecological Land Classification Framework for the United States." USDA. Miscellaneous Publication 1439. Washington, DC.

Faith, D.P. (1991). "Effective Pattern Analysis Methods for Nature Conservation." In: Nature conservation: cost effective biological surveys. Commonwealth Scientific and Industrial Research Organization, Australia, pp 47-53. 
Fautin, R.W. (1946). "Biotic Communities of the Northern Desert Shrub Biome in Western Utah." Ecological Monographs (16), pp 251-310.

Federal Geographic Data Committee-Vegetation Subcommittee. (3 June 1996). FGDC Vegetation Classification and Information Standards. USGS Reston, VA.

Fenneman, N.W. (1931). Physiography of the Western United States. McGraw Hill, New York, New York.

Francis, R.E., and E.F. Aldon. (1987). "An Ecological Approach to Classifying Semi-arid plant Communities." In: Strategies for Classification and Management of Native Vegetation for Food Production in Arid Zones. Forest Service General Technical Report: RM-150. pp 9-14. Rocky Mountain Forest Experiment Station.

Gates, D.H., L.A. Stoddard, and C.W. Cook. (1956). "Soil as a Factor Influencing Plant Distributions on Salt Deserts in Utah." Ecological Monographs 36: pp 155-174.

Gauch, H.G. (1982). “Multivariate Analysis in Community Ecology.” Beck, E., Birks, H.J.B., and Connor, E.F., eds., Cambridge University Press, New York.

Gauch, H.G., Jr. and R.H. Whittaker. (1981). "Hierarchical Classification of Community Data," Journal of Ecology 69, pp 237-557.

Holmgren, R.C. (1983). “The Great Basin Cold Desert: Some Physical Geography” In: Proceedings-Symposium on the Biology of Atriplex and Related Chenopods. Forest Service General Technical Report: INT-172. pp 108-113. Intermountain Forest and Range Experiment Station, Ogden, Utah.

Kent, M., and Coker, P. (1992). Vegetation description and analysis. Bellhaven Press, London, England.

Krebs, C. (1989). Ecological methodology. Harper and Row, Publishers; New York.

Küchler, A.W. (1970). "Potential Natural Vegetation Map." In: The National Atlas of The U.S.A. pp 90-91. U.S. Government Printing Office, Washington, DC.

Küchler, A.W. (1988). "The Classification of Vegetation," Vegetation Mapping, (Handbook of Vegetation Science, Volume 10), pp 67-80. A.W. Küchler and I.S. Zonneveld eds. Dordrecht, Netherlands: Kluwer Academic Publishers.

McArthur, E.D. (1981). "Taxonomy, Origin and Distribution of Big Sagebrush (Artemisia tridentata) and Allies (Subgenus Tridentatae)." In: Proceedings of the First Utah Shrub Ecology Workshop. pp. 3-13. College of Natural Resources, Utah State University, Logan, Utah.

Minchin, P.R. (1987). "An Evaluation of the Relative Robustness of Techniques for Ecological Ordination." Vegetatio (currently Plant Ecology) 67, pp 1167-1179.

Mueller-Dombois, D., and H. Ellenberg. (1974). "Aims and Methods of Vegetation Ecology." John Wiley and Sons, New York. 
Moir W.H., and J.O. Carleton. (1987). "Classification of Pinyon-Juniper on National Forests In the Southwest." In: Proceedings-Pinyon-Juniper Conference. pp 216-226. Forest Service General Technical Report: INT-215. Intermountain Research Station, Reno, Nevada.

Podani, J. (1993). SYN.TAX-pc Computer Programs for Multivariate Data Analysis in Ecology and Systematics, Version 5.0, Scientia Publishing, Budapest, Hungary.

Poore, M.E.D. (1955). “The Use of Phytosociological Methods in Ecological Investigations," Journal of Ecology 43, pp 226-269.

Roundy, B.A., R.A. Evans, and J.A. Young. (1983). "Surface Soil and Seedbed Ecology In SaltDesert Plant Communities." In: Proceedings-Symposium on the Biology of Atriplex and Related Chenopods. pp. 66-74. Forest Service General Technical Report: INT-163. Intermountain Forest and Range Experiment Station, Ogden, Utah.

Shantz, H.L. (1925). "Plant Communities in Utah and Nevada." In: Tidestrom, Flora of Utah and Nevada. U.S. National Herbarium no. 25. pp 15-23. Smithsonian Institution, Washington, DC.

Shimwell, D.W. (1971). The Description and Classification of Vegetation. University of Washington Press, Seattle.

Stephens, J.C. and C.T. Sumison. (1978). "Hydrologic Reconnaissance of the Dugway ValleyGovernment Creek area, West-central Utah." Technical publication no. 59, State of Utah, Department of Natural Resources.

The Nature Conservancy. (December 1994a). "Field methods for vegetation mapping," Final Draft, National Biological Survey/National Park Service Vegetation Mapping Program, Arlington, Virginia.

The Nature Conservancy. (December 1994b). "Standardized national vegetation classification system," Final Draft, National Biological Survey/National Park Service Vegetation Mapping Program, Arlington, Virginia.

Tueller, P.T., C.D. Beeson, R.J. Tausch, N.E. West, and K.H. Rea. (1979). “Pinyon-Juniper Woodlands of the Great Basin: Distribution, Flora, Vegetal Cover." USDA Forest Service Research Paper INT-229. Intermountain Forest and Range Experiment Station.

United Nations Educational, Scientific and Cultural Organization (UNESCO). (1973). International Classification and Mapping of Vegetation, Series 6, Ecology and Conservation. United Nations Educational, Scientific and Cultural Organization. Paris, France.

U.S. Soil Conservation Service (USSCS). (1986). "Dugway Proving Ground, Utah Soil and Range Survey." Salt Lake City, Utah.

van Tongeren, O.F.R. (1987). "Cluster Analysis." In: Data Analysis in Community and Landscape Ecology. R.H.G. Jongman, C.J.F. ter Braak, and O.F.R. van Tongeren, eds. Cambridge University Press. Cambridge.

Vest, D.E. (1955). "Biotic Communities as Epizootic Highways." Symposium on Ecology of Disease Transmission in Native Animals, Dugway Proving Ground. 
Vest, D.E. (1962). "Biotic Communities in the Great Salt Lake Desert." Ecology and Epizoology Series No.73, Institute of Environmental Biological Research, Division of Biological Sciences, University of Utah.

Welsh, S.L., N.D. Atwood, S. Goodrich, and L.C. Higgins. (1993). “A Utah Flora” Print Services, Brigham Young University, Provo, Utah.

West, N.E. (1979). "Basic Synecological Relationships of Sagebrush-Dominated Lands in the Great Basin and the Colorado Plateau." In: The Sagebrush Ecosystem: A Symposium. pp. 3341. Utah State Univeristy, College of Natural Resources, Ogden, Utah.

West, N.E. (1982). "Dynamics of Plant Communities Dominated by Chenopod Shrubs." International Journal of Ecology and Environmental Science. 8: pp 73-84.

West, N.E. (1988). "Intermountain Deserts, Shrub Steppes, and Woodlands." In: North American Terrestrial Vegetation. M.G. Barbour and W.D. Billings, eds. Cambridge University Press, New York, New York. pp 209-229.

Whittaker, R.H. (1973). "Approaches to classifying vegetation." Handbook of Vegetation Science. R. Tuxen, ed., $5^{\text {th }}$ ed., Dr. W. Junk b.v., Netherlands, pp 323-354.

Zamora, B. and P.T. Tueller. (1973). "Artemisia arbuscula, A. longiloba, and A. Nova Habitat Types in Northern Nevada." Great Basin Naturalist. 33: pp 225-242.

Zonneveld, I.S. (1988). "Survey Approaches." In: Handbook of Vegetation Science, Vegetation Mapping, Volume 10, pp 203-207. A.W. Küchler and I. S. Zonneveld, eds. Dordrecht, Netherlands: Kluwer Academic Publishers. 


\section{Appendix}

Table A-1. Mean vegetative cover and constancy of the most common species at DPG in the 26 identified associations and 1 formation at DPG.

\begin{tabular}{|c|c|c|c|c|c|c|c|c|c|c|c|c|}
\hline \multirow[t]{2}{*}{ Association } & \multicolumn{2}{|c|}{$\begin{array}{c}\text { Juos-mixed } \\
\text { grass } \\
\end{array}$} & \multicolumn{2}{|c|}{ Juos } & \multicolumn{2}{|c|}{ Juos Elsp/Arno } & \multicolumn{2}{|c|}{ Arno } & \multicolumn{2}{|c|}{$\begin{array}{c}\text { Artr. (var wyom.)/ } \\
\text { Pose }\end{array}$} & \multicolumn{2}{|c|}{ Artr/Juos } \\
\hline & Con. & Cov. & Con. & Cov. & Con. & Cov. & Con. & Cov. & Con. & Cov. & Con. & Cov. \\
\hline \multicolumn{13}{|l|}{ Tree } \\
\hline Juos & 1.0 & 12.8 & 1.0 & 21.5 & 1.0 & 4.5 & 0.1 & 0.2 & & & 1.0 & 2.5 \\
\hline \multicolumn{13}{|l|}{ Shrub } \\
\hline Arno & 0.2 & 0.5 & & & 1.0 & 8.5 & 1.0 & 24.8 & & & & \\
\hline Artr var wyom. & 0.1 & 0.7 & & & & & & 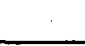 & 1.0 & 33.0 & & \\
\hline Artr & 0.3 & 1.7 & 0.4 & 0.7 & & & & & & & 1.0 & 35.0 \\
\hline Chvi & 0.8 & 1.0 & 0.3 & 0.5 & 0.9 & 0.9 & 0.7 & 0.8 & 1.0 & 1.3 & 1.0 & 4.5 \\
\hline \multicolumn{13}{|l|}{ Chna } \\
\hline Chna var. turb. & 0.2 & 0.3 & 0.4 & 0.3 & 0.1 & 0.1 & & & & & & \\
\hline Emu & 0.3 & 1.0 & 0.5 & 0.5 & & & & & & & & \\
\hline Atco & 0.3 & 0.3 & & & 0.2 & 0.2 & 0.7 & 1.3 & 1.0 & 1.2 & 0.5 & 0.9 \\
\hline Atca & 0.2 & 0.2 & 0.8 & 1.8 & & & & & & & 0.3 & 0.6 \\
\hline \multicolumn{13}{|l|}{ Alga } \\
\hline Koam & & & & & & & 0.3 & 0.3 & & & & \\
\hline Gusa & 0.5 & 1.0 & 0.8 & 1.6 & 0.2 & 0.2 & 0.3 & 0.3 & 0.2 & 0.2 & 0.3 & 0.3 \\
\hline Save & 0.1 & 0.1 & & & & & 0.1 & 0.1 & 0.2 & 3.0 & & \\
\hline Epne & 0.2 & 0.3 & 0.3 & 0.3 & 0.6 & 0.7 & 0.5 & 0.6 & 0.4 & 0.9 & 0.5 & 0.5 \\
\hline \multicolumn{13}{|l|}{ Aloc } \\
\hline \multicolumn{13}{|l|}{ Herbaceous } \\
\hline Psla & 0.2 & 0.6 & 0.3 & 0.3 & & & & & & & & \\
\hline \multicolumn{13}{|l|}{ Ardr } \\
\hline Pose & 0.5 & 0.7 & & & 0.7 & 0.9 & 0.8 & 1.0 & 1.0 & 11.0 & 0.8 & 0.8 \\
\hline Elel & 0.2 & 0.2 & 0.2 & 0.2 & 0.2 & 0.2 & 0.5 & 0.5 & 0.6 & 0.5 & 0.5 & 0.9 \\
\hline Brte & 0.8 & 3.0 & 1.0 & 28.0 & 0.3 & 0.3 & 0.9 & 7.3 & 1.0 & 0.9 & 1.0 & 19.7 \\
\hline Elsp & 0.4 & 2.0 & & & 1.0 & 9.7 & 0.3 & 0.3 & & & & \\
\hline Hija & 0.3 & 0.3 & 0.5 & 0.6 & 0.1 & 0.1 & 0.5 & 1.2 & 0.2 & 0.5 & 0.3 & 0.6 \\
\hline Sthy & 0.5 & 0.8 & 0.8 & 1.2 & 0.1 & 0.1 & 0.5 & 0.4 & 0.2 & 0.2 & 0.5 & 0.5 \\
\hline Spar & & & & & & & 0.1 & 0.1 & & & & \\
\hline
\end{tabular}

* Association names were derived from the dominant species in terms of cover and constancy in each association. 
Table A-1. continued.

\begin{tabular}{|c|c|c|c|c|c|c|c|c|c|c|c|c|}
\hline \multirow[t]{2}{*}{ Association } & \multicolumn{2}{|c|}{ Artr } & \multicolumn{2}{|c|}{ Chvi } & \multicolumn{2}{|c|}{ Chna } & \multicolumn{2}{|c|}{ Gusa } & \multicolumn{2}{|c|}{ Emu } & \multicolumn{2}{|c|}{ Psla } \\
\hline & Con. & Cov. & Con. & Cov. & Con. & Cov. & Con. & Cov. & Con. & Cov. & Con. & Cov. \\
\hline \multicolumn{13}{|l|}{ Tree } \\
\hline Juos & 0.1 & 0.1 & & & & & & & 0.3 & 0.3 & & \\
\hline \multicolumn{13}{|l|}{ Shrub } \\
\hline \multicolumn{13}{|l|}{ Amo } \\
\hline \multicolumn{13}{|l|}{$\begin{array}{l}\text { Artr var } \\
\text { wyom. }\end{array}$} \\
\hline Artr & 1.0 & 25.1 & & & 0.3 & 0.7 & 0.1 & 0.1 & & & & \\
\hline Chvi & 0.7 & 1.1 & 1.0 & 15.0 & 0.6 & 1.2 & 0.3 & 0.6 & 0.5 & 0.9 & 0.2 & 0.4 \\
\hline Chna & & & & & 1.0 & 16.4 & & & & & & \\
\hline $\begin{array}{l}\text { Chna var. } \\
\text { turb. }\end{array}$ & 0.1 & 0.1 & 0.3 & 0.3 & 0.6 & 11.8 & & & 0.3 & 0.6 & 0.3 & 0.6 \\
\hline Ernu & & & 1.1 & 0.4 & 0.1 & 0.4 & 0.2 & 0.2 & 1.0 & 11.9 & 0.7 & 0.9 \\
\hline Atco & 0.5 & 1.1 & 0.1 & 0.1 & 0.1 & 0.1 & 0.3 & 0.3 & & & & \\
\hline Atca & 0.2 & 0.6 & 0.1 & 0.1 & 0.4 & 0.4 & 0.4 & 0.9 & 0.3 & 0.3 & 0.2 & 0.2 \\
\hline \multicolumn{13}{|l|}{ Atga } \\
\hline Koam & 0.1 & 0.1 & & & & & 0.2 & 0.4 & & & & \\
\hline Gusa & 0.3 & 0.7 & & & & & 1.0 & 17.3 & & & 0.2 & 0.4 \\
\hline Save & 0.1 & 0.5 & 0.1 & 0.4 & & & 0.3 & 0.6 & & & & \\
\hline Epne & 0.4 & 1.3 & & & 0.1 & 0.1 & 0.2 & 0.2 & & & & \\
\hline \multicolumn{13}{|l|}{ Aloc } \\
\hline \multicolumn{13}{|l|}{ Herbaceous } \\
\hline Psla & & & 0.4 & 0.9 & 0.1 & 0.4 & & & 0.8 & 5.0 & 1.0 & 18.1 \\
\hline Ardr & & & 0.1 & 0.1 & & & & & & & 0.5 & 13.1 \\
\hline Pose & 0.3 & 0.3 & & . & & & 0.2 & 0.2 & & & & \\
\hline Elel & 0.5 & 0.5 & 0.1 & 0.7 & 0.4 & 0.4 & 0.3 & 0.5 & & & & \\
\hline Brte & 1.0 & 22.9 & 1.0 & 5.6 & 1.0 & 4.1 & 0.9 & 19 & 1.0 & 10.1 & 11.6 & 0.8 \\
\hline Elsp & 0.1 & 0.4 & & & & & & & & & & \\
\hline $\mathrm{Hija}$ & 0.2 & 0.3 & 0.1 & 0.4 & & & & & & & & \\
\hline Sthy & 0.6 & 0.7 & 0.9 & 1.3 & 0.7 & 1.1 & 0.6 & 0.6 & 1.0 & 1.4 & 1.0 & 3.5 \\
\hline Spar & & & & & & & & & & & & \\
\hline
\end{tabular}


Table A-1. continued.

\begin{tabular}{|c|c|c|c|c|c|c|c|c|c|c|c|c|}
\hline \multirow[t]{2}{*}{ Association } & \multicolumn{2}{|c|}{ Atco } & \multicolumn{2}{|c|}{ Spar } & \multicolumn{2}{|c|}{ Atca } & \multicolumn{2}{|c|}{ Alga } & \multicolumn{2}{|c|}{ Epne } & \multicolumn{2}{|c|}{ Koam } \\
\hline & Con. & Cov. & Con. & Cov. & Con. & Cov. & Con. & Cov. & Con. & Cov. & Con. & Cov. \\
\hline \multicolumn{13}{|l|}{ Tree } \\
\hline Juos & & & & & & & & & 0.3 & 0.6 & & \\
\hline \multicolumn{13}{|l|}{ Shrub } \\
\hline \multicolumn{13}{|l|}{ Arno } \\
\hline \multicolumn{13}{|l|}{$\begin{array}{l}\text { Artt var } \\
\text { wyom. }\end{array}$} \\
\hline Antr & 0.1 & 0.1 & & & & & & & 0.9 & 0.5 & & \\
\hline Chvi & 0.1 & 0.3 & & & 0.4 & 0.9 & & & 0.3 & 0.3 & & \\
\hline \multicolumn{13}{|l|}{ Chna } \\
\hline $\begin{array}{l}\text { Chna var. } \\
\text { turb. }\end{array}$ & & & 0.5 & 0.5 & 0.1 & 0.1 & & & & & & \\
\hline Emu & & & & & 0.4 & 0.9 & & & & & & \\
\hline Atco & 1.0 & 28.3 & 0.5 & 0.5 & & & 1.0 & 1.8 & 0.3 & 0.3 & 0.8 & 1.3 \\
\hline Atca & & & & & 1.0 & 13.2 & & & 0.3 & 0.6 & & \\
\hline Atga & & & 0.5 & 0.5 & & & 1.0 & 15.0 & & & 0.3 & 0.6 \\
\hline Koam & 0.4 & 2.8 & & & & & 1.0 & 2.5 & & & 1.0 & 18.0 \\
\hline Gusa & 0.1 & 0.1 & 0.5 & 0.5 & & & & & 0.3 & 0.6 & & \\
\hline Save & 0.1 & 0.8 & & & 0.3 & 0.3 & & & & & 0.9 & 3.5 \\
\hline Epne & 0.1 & 0.1 & & & & & & & 1.0 & 20.6 & & \\
\hline Aloc & & & 0.5 & 0.5 & & & & & . & & & \\
\hline \multicolumn{13}{|l|}{ Herbaceous } \\
\hline Psla & 0.2 & 0.2 & & & 0.3 & 0.5 & & & & & & \\
\hline \multicolumn{13}{|l|}{ Ardr } \\
\hline Pose & 0.3 & 0.2 & & & & & 1.0 & 0.3 & 0.3 & 0.3 & & \\
\hline Elel & 0.9 & 1.2 & & & & & & & 0.1 & 0.3 & 0.3 & 0.3 \\
\hline Brte & 1.0 & 27.5 & & & 1.0 & 21.2 & 1.0 & 1.8 & 1.0 & 38.8 & 0.8 & 1.8 \\
\hline \multicolumn{13}{|l|}{ Elsp } \\
\hline Hija & 0.1 & 0.1 & & & 0.1 & 0.1 & & & 0.5 & 0.9 & & \\
\hline Sthy & 0.1 & 0.1 & & & 0.7 & 3.1 & & & 0.8 & 1.1 & & \\
\hline Spar & & & 1.0 & 37.5 & & & & & & & & \\
\hline
\end{tabular}


Table A-1. continued.

\begin{tabular}{|c|c|c|c|c|c|c|c|c|c|c|c|c|}
\hline \multirow[t]{2}{*}{ Association } & \multicolumn{2}{|c|}{ Save } & \multicolumn{2}{|c|}{ Aloc } & \multicolumn{2}{|c|}{ Mixed Shrub } & \multicolumn{2}{|c|}{ Pose } & \multicolumn{2}{|c|}{ Elel } & \multicolumn{2}{|c|}{ Elsp } \\
\hline & Con. & Cov. & Con. & Cov. & Con. & Cov. & Con. & Cov. & Con. & Cov. & Con. & Cov. \\
\hline \multicolumn{13}{|l|}{ Tree } \\
\hline Juos & & & & & 0.1 & 0.1 & & & & & 0.5 & 1.1 \\
\hline \multicolumn{13}{|l|}{ Shrub } \\
\hline Amo & & & & & 0.1 & 0.3 & & & & & 0.8 & 12.5 \\
\hline $\begin{array}{l}\text { Artr var } \\
\text { wyom. }\end{array}$ & & & & & 0.1 & 0.1 & & & & & & \\
\hline Antr & 0.1 & 0.2 & & & 0.1 & 0.1 & & & & & & \\
\hline Chvi & & & 0.3 & 0.3 & 0.6 & 0.8 & & & & & 0.9 & 0.9 \\
\hline \multicolumn{13}{|l|}{ Chna } \\
\hline $\begin{array}{l}\text { Chna var. } \\
\text { turb. }\end{array}$ & & & & & 0.3 & 0.5 & & & & & & \\
\hline Emu & & & & & 0.3 & 0.4 & & & & & & \\
\hline Alco & 0.4 & 0.7 & & & 0.5 & 0.8 & 1.0 & 1.8 & 0.5 & 0.5 & 0.8 & 0.8 \\
\hline Atca & 0.1 & 0.7 & 0.5 & 0.5 & 0.4 & 0.5 & & & & & & \\
\hline Atga & & & & & 0.1 & 0.1 & & & & & & \\
\hline Koam & 0.5 & 0.8 & 0.3 & 0.3 & 0.4 & 0.6 & 0.5 & 1.0 & & & & \\
\hline Gusa & 0.1 & 0.1 & & & 0.6 & 0.9 & 0.5 & 0.5 & 0.3 & 0.6 & 0.4 & 0.8 \\
\hline Save & 1.0 & 17.8 & & & 0.3 & 0.5 & & & & & & \\
\hline Epne & & & & & 0.2 & 0.3 & & & 0.3 & 0.3 & 0.4 & 0.6 \\
\hline Aloc & 0.1 & 0.1 & 1.0 & 5.3 & & & & & & & & \\
\hline \multicolumn{13}{|l|}{ Herbaceous } \\
\hline Psla & & & & & 0.2 & 0.3 & & & & & & \\
\hline Ardr & & & & & 0.1 & 0.1 & & & & . & & \\
\hline Pose & & & & & 0.3 & 0.4 & 1.0 & 15.0 & & & 0.9 & 8.9 \\
\hline Elel & 0.4 & 0.4 & & & 0.3 & 0.3 & 0.5 & 0.5 & 1.0 & 2.5 & & \\
\hline Brte & 0.9 & 19.4 & 0.3 & 0.3 & 0.9 & 3.9 & 1.0 & 1.8 & 1.0 & 2.1 & 0.8 & 3.0 \\
\hline Elsp & & & & & 0.1 & 0.1 & & & & & 1.0 & 15.0 \\
\hline Hija & & & & & 0.2 & 0.3 & 0.5 & 0.5 & & & 0.5 & 0.5 \\
\hline Sthy & 0.1 & 0.1 & & & 0.7 & 0.8 & 0.5 & 0.5 & 0.5 & 1.3 & 0.1 & 0.1 \\
\hline Spar & & & & & 0.2 & 0.4 & 0.5 & 1.3 & & & & \\
\hline
\end{tabular}


Table A-1. continued.

\begin{tabular}{|c|c|c|c|c|c|c|c|c|c|c|c|c|}
\hline \multirow[t]{2}{*}{ Association } & \multicolumn{2}{|c|}{ Hija } & \multicolumn{2}{|c|}{ Sthy } & \multicolumn{2}{|c|}{ Brte } & & & & & & \\
\hline & Con. & Cov. & Con. & Cov. & Con. & Cov. & & & & & & \\
\hline \multicolumn{13}{|l|}{ Tree } \\
\hline \multicolumn{13}{|l|}{ Juos } \\
\hline \multicolumn{13}{|l|}{ Shrub } \\
\hline \multicolumn{13}{|l|}{ Amo } \\
\hline \multicolumn{13}{|l|}{ Artr var wyom. } \\
\hline Antr & 0.5 & 1.3 & & & 0.1 & 0.4 & & & & & & \\
\hline Chvi & 0.5 & 0.5 & & & 0.4 & 0.9 & & & & & & \\
\hline Chna & & & & & 0.1 & 0.1 & & & & & & \\
\hline Chna var. turb. & & & & & 0.1 & 0.1 & & & & & & \\
\hline Ernu & 0.5 & 0.5 & & & 0.2 & 0.3 & & & & & & \\
\hline Atco & 0.5 & 0.5 & 0.5 & 0.3 & 0.2 & 0.3 & & & & & & \\
\hline Atca & & & & & 0.2 & 0.5 & & & & & & \\
\hline \multicolumn{13}{|l|}{ Atga } \\
\hline Koam & 0.5 & 0.5 & 0.5 & 0.5 & 0.1 & 0.1 & & & & & & \\
\hline Gusa & 0.5 & 0.5 & & 0.4 & 0.5 & & & & & & & \\
\hline Save & & & & & 0.3 & 0.5 & & & & & & \\
\hline Epne & & & 0.5 & 0.5 & 0.2 & 0.5 & & & & & & \\
\hline \multicolumn{13}{|l|}{ Aloc } \\
\hline \multicolumn{13}{|l|}{ Herbaceous } \\
\hline Psla & & & & & 0.2 & 0.3 & & & & & & \\
\hline \multicolumn{13}{|l|}{ Ardr } \\
\hline Pose & 0.5 & 0.5 & 1.0 & 2.5 & 0.1 & 0.1 & & & & & & \\
\hline Elel & & & 1.0 & 1.8 & 0.1 & 0.4 & & & & & & \\
\hline Brte & 1.0 & 19.3 & 1.0 & 8.0 & 1.0 & $\begin{array}{r}15.0- \\
97.5 \\
\end{array}$ & & & & & & \\
\hline Elsp & & & & & 0.1 & 0.1 & & & & & & \\
\hline Hija & 1.0 & 26.3 & & & 0.2 & 0.3 & & & & & & \\
\hline Sthy & & & 1.0 & 15.0 & 0.5 & 0.8 & & & & & & \\
\hline Spar & & & & & 0.1 & 0.1 & & & & & & \\
\hline
\end{tabular}


Table A-2. Elevation, slope, and occurrence of the 26 identified associations and 1 formation occurring at DPG.

\begin{tabular}{|c|c|c|c|c|c|}
\hline \multirow[b]{2}{*}{ Association } & \multicolumn{2}{|c|}{ Elevation (m) } & \multicolumn{2}{|c|}{ Slope } & \multirow[b]{2}{*}{ \# of Sites } \\
\hline & Range (m) & Avg. & $\begin{array}{c}\text { Slope Range } \\
(\%)\end{array}$ & $\begin{array}{c}\text { Avg. Slope } \\
(\%)\end{array}$ & \\
\hline $\begin{array}{l}\text { Juniperus osteosperma-mixed } \\
\text { grass }\end{array}$ & $1403-1983$ & 1566 & $0-54$ & 15.6 & 31 \\
\hline Juniperus osteosperma & $1346-1484$ & 1386 & $0-10$ & 3.5 & 12 \\
\hline $\begin{array}{l}\text { Juniperus osteosperma-Elymus } \\
\text { spicatum/Artemisia nova }\end{array}$ & $1418-2018$ & 1581 & $8-35$ & 24.4 & 18 \\
\hline Artemisia nova & $1431-1965$ & 1644 & $0-29$ & 9.1 & 31 \\
\hline $\begin{array}{l}\text { Artemisa tridentata var. } \\
\text { wyomingensis/Poa secunda }\end{array}$ & $1455-1530$ & 1508 & $16-46$ & 27.6 & 5 \\
\hline $\begin{array}{l}\text { Artemisia tridentata/ Juniperus } \\
\text { osteosperma }\end{array}$ & $1455-1546$ & 1498 & $4-50$ & 19 & 4 \\
\hline Artemisia tridentata & $1321-1860$ & 1503 & $0-25$ & 4.6 & 44 \\
\hline Chrysothamnus viscidfilorus & $1349-1498$ & 1451 & 0.5 & 1.1 & 7 \\
\hline Chrysothamnus naseousus & $1424-1502$ & 1471 & 0.7 & 2.0 & 7 \\
\hline Gutierezia sarothae & $1321-1497$ & 1375 & $0-25$ & 4.7 & 10 \\
\hline Eriogonum nummulare & $1317-1424$ & 1370 & $0-10$ & 3.5 & 4 \\
\hline Psoralidium lanceolatum & $1314-1490$ & 1395 & $0-10$ & 3 & 6 \\
\hline Atriplex confertifolia & $1342-1503$ & 1438 & $0-25$ & 2.1 & 19 \\
\hline Atriplex canescens & $1320-1483$ & 1418 & $0-4$ & 1.0 & 7 \\
\hline Atriplex gardneri & 1415 & 1415 & 0 & 0 & 2 \\
\hline Mixed Shrub Formation & $1304-1793$ & 1434 & $0-45$ & 3.2 & 67 \\
\hline Ephedra nevadensis & $1434-1825$ & 1558 & 0.8 & 5.0 & 4 \\
\hline Kochia americana & $1322-2036$ & 1561 & 0 & 0 & 15 \\
\hline Sarcobatus vermiculatus (low) & $1307-1473$ & 1405 & $0-4$ & 0.1 & 23 \\
\hline Sarcobatus vermiculatus (high) & $1571-2078$ & 1926 & 0 & 0 & 4 \\
\hline Allenrolfea occidentalis & $1313-1314$ & 1313 & 0 & 0 & 4 \\
\hline Poa secunda & $1356-1510$ & 1433 & $0-61$ & 30.5 & 2 \\
\hline Elymus elymoides & $1388-1498$ & 1461 & $0-6$ & 2.8 & 4 \\
\hline Elymus spicatum & $1482-1679$ & 1556 & $15-24$ & 27.8 & 8 \\
\hline Hiliaria jamesii & 1310 & 1310 & $0-7$ & 3.5 & 2 \\
\hline Stipa hymenoides & $1533-1538$ & 1545 & $22-29$ & 25.5 & 2 \\
\hline Bromus tectorum & $1306-1866$ & 1423 & $0-40$ & 3.7 & 112 \\
\hline Sporobolus airoides & no data & no data & no data & no data & 2 \\
\hline
\end{tabular}




\section{USACERL DISTRIBUTION}

\section{Chief of Engineers}

ATTN: CEHEC-IM-LH (2)

ATTN: CEHEC-IM-LP (2)

ATTN: CECC-R

ATTN: CERD-L

ATTN: CERD-M

Dugway Proving Ground

ATTN: STEDP-EP-CP (5)

Defense Tech Info Center 22304

ATTN: DTIC-O (2) 